\title{
Előzetes eredmények egy magyar mintán kidolgozott Intrauterin Kapcsolati Kérdôív méréses tapasztalatairól - pilot study
}

\author{
Az anya-magzat kapcsolat párkapcsolattal \\ és szülői bánásmóddal való összefüggéseinek vizsgálata
}

\author{
HADHÁZI ÉVA ${ }^{1 *}$ - ANDREK ANDREA² - KEKECS ZOLTÁN ${ }^{3}$ \\ ${ }^{1}$ Károli Gáspár Református Egyetem, Pszichológiai Intézet, \\ Fejlődéslélektani Tanszék, Budapest \\ ${ }^{2}$ Eötvös Loránd Tudományegyetem, Affektív Pszichológiai Tanszék, Budapest \\ ${ }^{3}$ Lund University, Department of Psychology, Lund, Sweden
}

(Beérkezett: 2016. november 9., elfogadva: 2017. május 30.)

Elméleti háttér: Az 1980-as évektől kutatják az „anyai környezet” magzati fejlődésre gyakorolt hatását, ám az eredmények nem konzekvensek az anya-magzat kapcsolatot befolyásoló tényezőket illetően. Cél: Magyar mintán kialakítani egy anya-magzat kapcsolatot mérő kérdőívet, valamint feltárni az intrauterin kötődésben meghatározó szerepet játszó jellegzetességeket. Módszerek: 114, 15 és 38 gesztációs hét közötti várandós anya vett részt a kutatásban, kitöltve az Intrauterin Kapcsolati Kérdőívet, a Maternal Fetal Attachment Scale magyar változatát (MFAS-HU), az Intimitás és a Szülői Bánásmód Kérdőívet. Eredmények: A kialakított 28 tételes Intrauterin Kapcsolati Kérdőív (IUKK) faktorstruktúrája illeszkedési mutatókban az elvárások alatt marad (RMSEA $=0,08 ; \chi^{2} / \mathrm{df}=1,645 ; \mathrm{NFI}=$ 0,85; CFI = 0,87). A 8 alskála Cronbach-alfa értékei 0,56-0,93 közöttiek. Explorátoros faktorelemezéssel sikerült egy jó kommunalitási tulajdonságokkal rendelkező rövidebb modellt kialakítani (IUKK-R), amely 12 tételt és 3 alskálát tartalmaz (RMSEA = 0,08; $\chi^{2} / \mathrm{df}=$ 1,660; NFI = 0,95; CFI = 0,96). Az IUKK-R Cronbach-alfa értékei magasak: 0,81-0,93. Elemzéseinkhez az IUKK-R modellt használtuk. Kérdőívünk korrelál az MFAS-HU-val, ugyanakkor a megragadott magzati kötődés dimenzióik nem teljesen átfedőek. A nemzetközi tapasztalatokkal nagyjából összhangban, az anya-magzat kapcsolat erősségében szignifikánsan magasabb értéket ér el az anya, ha bármelyik tényezó jellemzi: házasságban él; magasabb az anyagi hozzájárulása a családi kasszához; nem volt korábban spontán vetélése, ő maga beavatkozástól mentesen, természetes módon született; biztosan tudja, vagy nem tudja a magzat nemét. Nem befolyásol a várandósság ideje, az iskolai végzettség, a várandósság tervezettsége, a fogantatás módja, a meglévő gyermekek száma és a magzatmozgás észlelése. A magzati kötődés összefügg a párkapcsolati intimitással: az észlelt gondoskodás kedvezőbb, míg az észlelt kontroll kedvezőtlenebb anya-magzat kötődéssel

\footnotetext{
* Levelező szerző: dr. Hadházi Éva, Károli Gáspár Református Egyetem, Bölcsészettudományi Kar, 1037 Budapest, Bécsi út 324. V. ép. E-mail: ahadhazi@enternet.hu
} 
jár együtt. Az anya saját szüleivel való kapcsolatának megélése, az anyai és apai szeretet, pozitívan korrelál a saját magzatához fúződő kapcsolattal. Következtetések: A magyar mintára kidolgozott kérdőív megbízhatósága ígéretes, de szükségesek további validitásvizsgálatok, nagyobb, heterogén mintán. Tapasztalataink felhívják a figyelmet a szülői bánásmód és a párkapcsolati gondoskodás jelentőségére a várandósság időszakában és gyakorlati relevanciával bírnak a prevenciós munkában.

Kulcsszavak: intrauterin kötődés, anya-magzat kapcsolat, párkapcsolati intimitás, szülői bánásmód

\section{Bevezetés}

Az utóbbi néhány évtized tudományos vizsgálatainak fényében megkérdőjelezhetetlen az "anyai környezet” magzati fejlődésre gyakorolt hatása. A magzati életben megtapasztaltak hosszú távon befolyásolják az egyén egészségének alakulását, ahogy arra Barker (1998) rámutat, a "magzati programozás hipotézis”-ben. Az anya jólléte, érzelmi kiegyensúlyozottsága, a magzatához fúződő kapcsolata egymástól nem elválasztható, a köldökzsinór és placentáris keringés lehetóvé teszi a szoros egymásra hatást az anya és méhében fejlődő magzata között (Hedegaard, Henriksen, Sabore, \& Secher, 1993; Kinsella \& Monk, 2009; Monk, Fifer, Myers, Sloan, Trien, \& Hurtado, 2000; Tegethoff, Greene, Olsen, Schaffner, \& Meinlschmidt, 2011). Az anyaméh, mint „elsődleges ökológiai környezet” (Hidas, 1997, 5. o.) a magzat számára egy interaktív világ, ahol a fogantatásával elindítja azokat a folyamatokat, amelyek fokozatosan aktivizálják az anyában a babára való irányulást. Az anyai attitúd már a születést, sőt fogantatást megelőzően létezik, a leendő anya saját tapasztalataiból, tudatos és tudattalan élményeiből, vágyaiból, fantáziáiból ered, és a várandósság létrejöttével, az új, konkrét tapasztalatok beépítésével folyamatosan gazdagodik, módosul és a magzathoz való viszonyulásban fejeződik ki (Hadházi, 2002).

A magzat létezése, fejlődése, reakciói révén egy sajátos dinamika alakul ki, amely megalapozza a kettejük közötti prenatális kötődést (Alhusan, 2008; Brandon, Pitts, Denton, Stringer, \& Evans, 2009; Cannella, 2005; Erickson, 1996). Kellő bevonódás mellett, a méhen belüli kapcsolat a magzattal kiterjed az anyát megtartó személyekre, elsősorban az apára (Bowen \& Miller, 1980), és kihatással lehet a késóbbi anya-csecsemó kapcsolatra (Damato, 2004; Siddiqui \& Hägglöf, 2000). Az anya és magzata közötti kötődésvizsgálatok jelentősége abban rejlik, hogy segítenek feltérképezni azokat a tényezőket, amelyek az anyai környezetre hatva befolyásolják a magzati fejlődést. Az eddigi vizsgálatok számos pszichológiai, demográfiai, szocioökonómiai tényezőt azonosítottak (Müller \& Mercer, 1993; Salisbury, Law, LaGasse, \& Lester, 2003), amelyek szerepet játszhatnak az anya és magzata közötti kötődés alakulásában. $S$ bár a kötődés maga univerzálisnak 
tekinthető, nincs egységes állásfoglalás a minőségét befolyásoló tényezők, például az esetleges kulturális különbségek meghatározásában (BielawskaBatorowicz \& Siddiqui, 2008). A szakirodalom megosztott azokat a tényezóket illetően, amelyek egyértelmúen befolyásolják az anya-magzat kötődést, holott a minél pontosabb ismeretük teszi lehetóvé, hogy bejósolhassuk az anya-magzat kapcsolat minőségét. Szükségünk van a magzati kötődés és komponenseinek mérésére alkalmas megbízható eszközökre ahhoz, hogy képesek legyünk felismerni a veszélyeztetett családokat, és intervenciók segítségével támogatni a kötődésükben elakadt várandósokat.

Vizsgálatunkban egy magyar mintán kidolgozott anya-magzat kapcsolatot mérő kérdőív érvényességét kívánjuk ellenőrizni és egyben megragadni néhány szociodemográfiai és pszichológiai tényezőt, amelyek hangolják az anya és magzata között kialakuló kapcsolatot.

\subsection{Mit takar az anya-magzat kötődés fogalma?}

Az új élet megfoganásával kialakul a szülőkben a fejlődő gyermekre való irányultság, mint a humán intimitás legalapvetőbb formája, amely tartalmazza a magzatról kialakított legkorábbi reprezentációkat, internalizált formában (Pisoni és mtsai, 2014).

A várandósság alatt, az anya és a benne fejlődő magzat között kialakuló kapcsolatot, a szakirodalom anya-magzat kötődésként tartja számon, amely egy meglehetősen új és nem elég pontosan meghatározott fogalom. Szinonimái a prenatális, illetve az antenatális kötődés. ${ }^{1}$ A terminológia (MFA: Maternal - Fetal Attachment, prenatal attachment, mother foetus bonding) minőségi meghatározása az anyai attitúdöknek és a terhességhez való alkalmazkodásnak, valamint a magzatról kialakult kognitív reprezentációknak. Doan és Zimerman (2003) szerint az anya-magzat kötődés egy absztrakt koncepció, amely az anya és magzata közötti affiliatív kapcsolatot reprezentálja, és már a terhesség előtt létezhet, hiszen azon érzelmi és kognitív készségünk eredménye, hogy képesek vagyunk egy másik ember képzeleti megalkotására és továbbfejlesztésére saját ökológiai rendszerünkön belül.

A téma szakértői a konstruktum különböző aspektusait helyezik előtérbe. Így Cranley (1981) az anya-magzat kötődés intenzitását az anya viselkedéses bevonódásának mértékével azonosítja, míg Müller (1993) az anya és

\footnotetext{
1 Tanulmányunkban a nemzetközi szakirodalomhoz hasonlóan mi is az anya-magzat kapcsolatra szinonimaként használjuk az intrauterin, a prenatális és az antenatális kötődés megnevezéseket.
} 
magzata között fejlődő egyedi kapcsolatként írja le, amelyben az érzelmeknek, gondolatoknak és fantáziának igen hathatós szerepe van. Condon (1993) pedig kognitív, érzelmi és altruisztikus dimenziókról beszél.

Salisbury és munkatársai (2003) összegzése szerint a prenatális kötődés magába foglalja az anya és magzata közötti elképzelt jeleneteket, forgatókönyveket, az anya által a magzatnak tulajdonított fizikai és érzelmi jellemvonásokat. Olyan viselkedéseket is felölel, amelyek a gondozásra, odaadásra utalnak, a magzatról való gondoskodást szolgálják (pl. a megfelelő táplálkozás, tartózkodás a káros anyagoktól), a magzat komfortérzetét növelik (pl. a pocak simogatása), és megteremtik fizikailag is a körülményeket az újszülött fogadására (pl. babaruhák vásárlása).

Az anya-magzat kötődést leginkább az anyai részről tudjuk megragadni. Rubin (1984) szerint az anyai kötődés magában az anyai identitásban rejlik, azaz, az anya részéről kialakuló mentális reprezentációk - csakúgy, mint Bolwby (1969) klasszikus értelemben vett kötődés fogalmánál -, szerves részét képezik az anya-magzat kötődésnek. Terápiás tapasztalatok is azt bizonyítják, hogy a magzat jóval a születés előtt belép az anya lelki valóságába (Hidas, Raffai, \& Vollner, 2008; Leff, 1993; Markin, 2013) és a várandósság alatt folyamatosan formálódik a születendő babáról kialakuló mentális reprezentáció az anyában, a megszületés idejéhez közeledve pedig egyre reálisabb babaképpé szerveződik. A magzati lét sajátosságaiból adódóan, bár mára a technikai lehetőségek révén - akár többdimenziós képet kínáló 3D, 4D ultrahang, a magzati szívfrekvencia és méhtevékenység mérésére alkalmas cardiotocographia, a magzatmozgást detektáló nonstressz teszt, a genetikai rendellenességek szúrésére alkalmazott magzatvízvizsgálat (amniocentézis), a magzatboholy mintavétel (chorionbiopsia), magzati köldökvérvétel (chordocentézis), stb. - korábban soha nem tapasztalt ismeretek birtokába jutottunk, még mindig nem tudjuk objektívnek elfogadott tudományos módszerekkel kelló mértékben meghatározni a magzati oldal reakcióit, a „kötődési viselkedését”.

Stocker és Hargitai (2007) szerint minőségében más a születés előtti, mint a születés utáni kötődés, hiszen a hangsúly nem a kölcsönösségen és viszonosságon van. A kötődés tárgya, bár fizikailag létező, az anya számára is csak korlátozott mértékben hozzáférhetó, vizuálisan nem (csak ultrahang vizsgálaton), taktilisen és interaktívan is csak közvetve az anya testén keresztül, azaz nélkülözi azokat a hagyományosan objektívnek tekintett adatokat a babáról, amelyek csak a születés után állnak rendelkezésre. Így nagy szerep jut az anyai fantáziáknak a kötődésben. Az új élet az anya testébe ágyazottan, folyamatos testi, lelki kapcsolatban fejlődik, a magzat a jelenlétével, egyre differenciáltabb megnyilvánulásaival maga is hat az anyára és a kettejük közötti kapcsolatra. 
Kutatások sora bizonyítja, hogy az anya állapota, viszonya a magzathoz alapvetően befolyásolja az újszülött életminőségét (Martin \& Dombrowski, 2008). A várandósság alatti anyai krónikus stressz, depresszió kedvezőtlen hatásait az utódra számos kutatás igazolta állatkísérletekben (Kinsella \& Monk, 2009) és humán vizsgálatokban egyaránt (Cardwell, 2013; Dunkel Schetter, 2011; Dunkel Schetter \& Tanner, 2012; Makino és mtsai, 2009; ld. Martin és Dombrowski, 2008 összefoglaló tanulmányát). Ezek szerint, a várandósság első trimeszterében erős stresszhatásnak kitett anyák gyermekeinél a kognitív múködésekért felelős agyterületeken fejlődésbeli eltérések tapasztalhatóak (ld. Charil, Laplante, Vaillancourt, \& King, 2010 összefoglaló munkáját). A kontrollálhatatlan érzelmi hatások olyan morfológiai és múködésbeli elváltozásokat okozhatnak az idegrendszerben, amelyek hatásai a későbbi életben fizikai, viselkedéses és kognitív fejlődésbeli elmaradásokban mutatkoznak meg (Buss, Davis, Muftuler, Head, \& Sandman, 2010; King \& Laplante, 2005).

Az anya-magzat kapcsolat jelentósége, nehéz megragadhatósága ellenére, igen inspiratívan hat a kutatásokra. Változatos módszertani elrendezéssel számos tapasztalat gyúlt össze, bár még mindig nem elegendó a fogalmi képlékenység és bizonytalanság eloszlatására.

\subsection{Létezhet-e kapcsolati kontinuitás a magzati és születés utáni kötődés között?}

Az 1970-es évektól kezdődően a korai érzelmi fejlődés modern kutatásai megállapították, hogy az újszülött bioszociális felkészültsége lehetővé teszi, hogy az anya és a csecsemő affektív kommunikációs rendszert alkosson a kezdetektől fogva. Az innátista felfogás szerint a csecsemó érzelmi állapotai közvetlen introspektív módon hozzáférhetőek, más nézetek szerint a tudatos érzelmek a szocializáció és a kognitív fejlődés eredményeként jelennek meg (Gergely \& Watson, 1998).

Gopnik (2009) szerint a kötődés hétköznapi nyelven maga a szeretet, amely tapasztalatok alapján alakul ki, és a múködésébe bele kell tanulni. Az empátiás készség már születéskor múködik, ami az utánzásban nyilvánul meg (nyelvöltés, alapérzelmek, egyszerú gesztusok) és intim kapcsolatban empátiává fejlődik, azaz „össze van fonódva a kötődéssel” (Gopnik, 2009, 201. o.).

Gergely és Watson (1998) is lehetségesnek tartják, hogy a csecsemők belső érzékleti benyomásokként, differenciálatlanul érzékeljenek bizonyos ingercsoportokat, amelyek az élmények pozitív, illetve negatív minőségeit adják. 
A csecsemók érzékelő rendszere már intrauterin is jól múködik (ld. magzati kompetenciák, Andrek, 1997; Chamberlain, 1998), így joggal feltételezhetó, hogy méhen belül érzékelik az érzelmeket implikáló akusztikus, kinetikus, stb. ingercsoportokat. Valamint az is elképzelhetó, hogy a magzat képes érzékelni, vagy osztozni az anyai érzelmekben, hiszen az érzelmek az anyában adrenalin, noradrenalin, kortizol, oxytocin, dopamin, szerotonin, endogén morfinok felszabadulásával járnak és 15-20\%-ban átjutnak a magzatba (Esch \& Stefano, 2005; Huizink, 2001; Kinsella \& Monk, 2009; Mulder és mtsai, 2002; van den Bergh, 1990). A magzat nemcsak érzékeli az anyai lelkiállapotot, hanem reagál is rá mozgással és szívritmus-változással. Ekképpen a méhen belül megtapasztalható szeretet is hozzájárulhat a gyermek szeretetről kialakuló világképéhez, a későbbi kötődéshez. DiPietro, Hodgson, Costigan és Johnson (1996) vizsgálatukban a születés előtt megjelenő stabil idegi és viselkedéses különbségek és a csecsemő temperamentuma között találtak kapcsolatot. A magzati múködésekre (aktivitás, szívritmus) úgy tekintenek, mint amelyek megalapozzák születés után a csecsemó reaktivitását és regulációját.

Empirikus kutatási tapasztalatok azt bizonyítják, hogy egyrészt a várandós anyák saját kötődési mintája, másrészt a magzati kötődés befolyásolják az anya-gyermek kapcsolat minőségét a születés után. Fónagy, Steele és Steele (1991) várandós anyák felnőtt kötődési reprezentációiból az esetek 75\%-ában sikeresen be tudták jósolni, hogy biztonságot nyújtó, vagy bizonytalan kötődést alakítanak-e ki saját gyermekeikkel a csecsemőjük 12 hónapos korában.

Müller (1996) az anyák magzataikhoz való kötődését mérte, majd összevetette a születés utáni kötődéssel. Mérsékelt erősségű összefüggést talált az intrauterin kötődés és a későbbi kapcsolat között $(r=0,41 ; p<0,001)$.

Siddiqui és Hägglöf (2000) szerint, a harmadik trimeszterben mért kötódésből bejósolható a szülést követő 12 hétben mért anya-baba interakció. Magas érték a Prenatal Attachment Inventory (PAI) "fantázia” faktoron nagyobb interakcióba való belevonódással járt. Aki magas értéket ért el az „interakció" és az „affekció" skálákon, az több proximális ingerlésben részesítette a babáját, míg, aki a "self differenciáció" skálán ért el magas pontot, az több disztális stimulációt biztosított. Az anya válaszkészsége a csecsemő figyelmességét jósolta be.

Damato (2004) ikervizsgálatokban közepes erősségú összefüggést talált a prenatális és posztnatális kötődés között $(r=0,38 ; p<0,001)$, és azonosította azokat a tényezőket, amelyek csökkentették a kapcsolat erősségét, ezek a szülés utáni depresszió, a császármetszés és az újszülöttkori intenzív ellátás igénybevétele. A prenatális kötődés és a szülés utáni depresszió 26,1\%-ban magyarázták a születés utáni kötődést. 
Mazzeschi, Pazzagli, Radi, Raspa és Burrata (2015) első gyermeküket váró anyákat vizsgáltak 7 hónapos várandósan és a szülést követően. Az anyák saját kötődési stílusa - főként a kapcsolati szorongás - negatívan korrelált a magzati kötődéssel és a párkapcsolati összeilléssel, míg a párkapcsolati összeillés és magzati kötődés között pozitív együttjárás mutatkozott. Mindegyik változó megbízhatóan jósolta be a szülés után 3 hónappal mért szülői szorongást, így potenciális rizikó tényezőnek tekintik a szerzők.

Az eddigi kutatások arra engednek következtetni, hogy a magzattal való kapcsolat, érzelmi viszonyulás érzékenyen érinti a méhen belüli fejlődést és mintegy előfeszíti a születés utáni kötődést.

\subsection{Kutatási tapasztalatok az anya-magzat kötődés vizsgálatáról}

Az 1980-as évektől kezdve történtek kísérletek az intrauterin kötődés operacionalizálására, mérésére. Cranley 1981-ben alkotta meg az Mother Fetus Attachment Scale-t (MFAS) amelynek 24 tétele a várandós anyák magzatukkal kapcsolatos viselkedésére, a várandósságra és születendő gyermekükre vonatkozó attitúdjeire vonatkozóan fogalmaz meg kijelentéseket. Ötfokozatú Likert-típusú skálán méri a magzathoz való kötődés intenzitását. Az eredetileg kialakított 5 alskálának a létjogosultsága megkérdőjelezhető (Beck, 1999), és magyar mintán is az összpontszám bizonyult a legmegbízhatóbbnak (Andrek, Kekecs, Hadházi, Boukydis, \& Varga, 2016).

Müller (1993) Prenatal Attachment Inventory (PAI) kérdőíve igen erőteljesen korrelál $(r=0,72)$ Cranley skálájával, ugyanakkor egy egyedi kapcsolati minőséget tételez, ami az anya és magzata között kifejlődik, az interakciók, érzelmek, magzati fantáziák, másokkal való örömmegosztás, és a saját és magzati selfet differenciáló dimenziók mentén. A magas PAI érték a terhességhez való jó adaptációt mutatja.

Condon (1993) Maternal Antenatal Attachment Scale (MAAS) hierarchikus modelljében 3 szinten próbálta megragadni a születés előtti kötődést a szubjektív tapasztalatok, diszpozíciók és felnőtt kötődési viselkedés mentén. Öt anyai diszpozíció, vagy szükséglet közvetít az élmények és a kötődési viselkedés között, ezek az alábbiak: a tudás/ismeret, együtt levés, a szeparáció vagy veszteség elkerülése, védelmezés, valamint a szükségletek kielégítése. Az anyai kötődés a diszpozíciók és a viselkedési sajátosságok elemzésével határozható meg. A 19 tételes kérdőív két dimenziót mér, a kötődés minőségét és intenzitását, a kötődés így alacsony és magas pontokkal jellemezhető. A kérdőivet a magyar adaptációját végző Sz. Makó és Deák (2014) is megbízhatónak találták. 
A nemzetközi és hazai kutatások eredményei egyaránt jól példázzák, hogy nehéz egy olyan modellt felállítani, amely lefedné azokat a területeket, amelyek befolyásolják az anya magzathoz való viszonyát.

Müller és Mercer (1993) kísérletet tettek arra, hogy bemutassák az anya magzatához fúződő kapcsolatát meghatározó tényezőket. Modelljük szerint az eredeti kötődési tapasztalatok határozzák meg a belső reprezentációkat, amelyek a késóbbi kötődési kapcsolatokat befolyásolják, egyrészt közvetlenül hatnak a magzathoz fúződő kötődésre, másrészt közvetetten, a partner, azaz párkapcsolati kötődésen keresztül befolyásolják a terhességhez való adaptálódást és hangolják a magzati kötődést.

Az eddigi tapasztalatok szerint az anya-magzat kötődési viselkedéseknek egy széles spektruma figyelhető meg, fóként a magzatmozgások megjelenését követően. Egyre intenzívebbé válik a várandósság előrehaladtával, bár befolyásolja a terhesség története és magának az anyának a kötődéstörténete (Lerum \& LoBiondo-Wood, 1989).

Metaelemzések eredményei szerint, az anya-magzat kötődés intenzitása - amit a skálák mérnek, elsősorban az MFAS - különböző mértékben, de bejósolható a várandósság idejéból, a társas támaszból és terhesgondozásból. Kevésbé erőteljes hatást gyakorol az anyai szorongás, önértékelés, depreszszió, a terhesség tervezettsége, életkor, terhességek száma, etnikai hovatartozás, családi állapot, bevétel és iskolázottság. A magas terhességi kockázat hatása is kimutatható, úgymint a rossz egészségi állapot, alacsony súlygyarapodás, droghasználat és dohányzás (Salisbury és mtsai, 2003; Yarcheski, Mahon, Yarcheski, Hanks, \& Cannella, 2009).

\subsection{A vizsgálat célja}

Az eddigi méréses tapasztalatok azt láttatják, hogy (a) az anya-magzat kötődés természetszerúen megjelenik a várandósság folyamán, hogy az egy belső szükséglete és igénye az anyának, és hogy (b) az állapotához fúződő pozitív megélések, a magzatára irányuló figyelem, gondoskodás és szeretet kedvez a kapcsolatuknak, a magzat fejlődésének (Condon, 1993; Cranley, 1981; Doan \& Zimerman, 2003, 2008; Müller, 1993; Müller \& Mercer, 1993; Siddiqui \& Hägglöf, 2000; Sz. Makó \& Deák, 2014). A kötődés intenzitását befolyásoló prediktorok egy része univerzálisnak tekinthető, például a magzatmozgások észlelése egyre valóságosabbá, jelenvalóbbá teszi a születendőt, interakcióra ösztönzi az anyát. Az egyéni élettörténet és a kulturális különbségek egyaránt hangolják a folyamatot, hiszen például a korábbi perinatális veszteségek szorongást generálhatnak, de, hogy hogyan gyászol az anya, illetve, hogy egyáltalán meggyászolható-e egy magzat, azt az adott kulturális elvárások befolyásolják. Hogy milyen érzelmi megnyilvánuláso- 
kat, gondozási és kapcsolódási formákat tart valaki elfogadhatónak a magzatával kapcsolatban, az nem független a családi normarendszertől, transzgenerációsan átadódó mintázatoktól és a tágabb értelemben vett környezet hagyomány- és szokásrendszerétől. Több mérőeszközt kifejlesztettek külföldön, amelyek közül leginkább az MFAS lett igazán populáris (1981 és 2006 között 50 tanulmányban használták; Yarcheski és mtsai, 2009), azzal együtt, hogy nem képes megbízhatóan mérni a kötődés aldimenzióit. Az anya-magzat kötődés prediktorainak meghatározása is nagyban függ a kutatások módszertani elrendezésétől, így további vizsgálatok szükségesek a bizonytalanságok minimalizálására.

Magyarországon a várandósgondozás egy törvényileg szabályozott komplex egészségügyi szolgáltatás (védőnő, háziorvos, a szülész-nőgyógyász szakorvos, a várandós választása esetén a szülésznó biztosítja), ami a várandóssal való együttmúködésén alapul és alanyi jogon jár. „A várandósgondozás célja a várandós nö egészségének megörzése, a magzat egészséges fejlödésének és egészségesen történö megszületésének elősegitése, a veszélyeztetettség és a szövődmények megelözése, illetve megfelelő időben történő felismerése, valamint a szülésre, a gyermek korai kötődésére, a szoptatásra és a csecsemőgondozásra való felkészítés." (Magyar Közlöny, 2014, 4937. o.). A törvényi keretekkel összhangban van az elgondolásunk, hogy prevenciós céllal, az anya-magzat kapcsolati nehézségekkel küzdő várandósokat ki lehessen szúrni és pszichológiai támogatásban részesíteni, ám ehhez mindenképpen szükségesek a megbízható, érzékeny méróeszközök.

Vizsgálatunkban kísérletet teszünk, a meglévő tapasztalatok integrálásával, a kötődést meghatározó prediktorokra minél érzékenyebb anya-magzat kötődést méró eszköz kidolgozására.

a) A szakirodalomra és várandósokkal folytatott gyakorlati munkatapasztalatainkra támaszkodva állítottuk össze a magzati kötődés mérésére hivatott kérdőívünket, megpróbálva azonosítani, hogy mely faktorok határozzák meg a magzati kötődést.

b) Vizsgálatunk olyan szociodemográfiai mutatókat vizsgál, amelyek nemzetközi tapasztalatok alapján prediktorai lehetnek a magzati kötődésnek, illetve - eredeti szempontokat bevonva -, olyanokat, amelyeket transzgenerációs szemléletben, a gyakorlati tapasztalataink alapján relevánsnak tételeztünk. Ezek a mutatók a korábbi perinatális veszteségek, az anya saját születésének körülményei, a magzat nemének ismerete, a párkapcsolati intimitás, az anyai szülői bánásmód és szüleinek családi állapota. Célunk, hogy megpróbáljuk - elsősorban magyar mintára fókuszálva megragadni azokat a jellegzetességeket, amelyek közelebb visznek az anya és magzata között kialakuló kapcsolat megértéséhez, olyan támpontokat adva a gyakorló szakembereknek, amelyek figyelembevételével segítséget nyújthatnak az édesanyáknak a magzatukra való ráhangolódásban. 


\section{Módszerek}

Jelen kutatás egy nagyobb átfogó vizsgálatsorozat részét képezi, amely az anya-magzat és az apa-magzat kötődést befolyásoló tényezöinek felderítését célozza. E tanulmányban csak az anya-magzat intrauterin kapcsolat mérésére, az eszköz validálására tett kísérlet eredményeinek bemutatására kerül sor.

\subsection{A vizsgálati minta bemutatása}

114 fós vizsgálatunkban, 23 és 44 év közötti (átlag: 31,87 év; SD = 4,27 év) primi $(70,2 \%)$ és multipara $(25,4 \%$ a második, 3,5\% a harmadik, és $0,9 \%$ a negyedik gyermekét váró) várandós vett részt. A beválogatás kritériumai a várandósság, az önkéntesség és az írástudás voltak. Várandósságuk ideje szerint a 15 és 38 (átlag: 27,11 hét; SD = 7,2 hét) gesztációs hét között, főként a második (48,3\%) és harmadik $(49,1 \%)$ trimesztert reprezentálhatják, mivel az első trimeszterbe csupán 3 fó (2,6\%) esett. Párkapcsolatukat tekintve homogénnek bizonyultak abból a szempontból, hogy 96,5\%-uk együtt él a magzat édesapjával (3,5\% úgy nyilatkozott, hogy nem él együtt a gyermek apjával), viszont státusz szerint megoszlanak, mivel 60,5\%-uk házasságban, 36,0\%-uk pedig házasságkötés nélkül él együtt. A párkapcsolatban élők átlag 51,5 hónapja (SD = 44,67 hónap) vannak együtt.

Mintánk többsége magas iskolázottságú nóből áll: főiskolai vagy egyetemi diplomával 64,0\% rendelkezik; felsőfokú tanulmányokat folytat $12,3 \%$; szakközépiskolai vagy gimnáziumi végzettséggel 17,5\% bír, és mindössze 6,1\% az, akinek szakmunkásképző a legmagasabb iskolai végzettsége.

Az anyagi helyzetüket tekintve önbevallás alapján $90 \%$-ban átlagos vagy a feletti jövedelemmel rendelkeznek: 10,7\% kissé az átlag alattinak, 50\% átlagosnak, 31,3 \% kissé az átlag felettinek, 8\% átlag felettinek értékelte a családja helyzetét. Ehhez az egzisztenciához az anyák 78\%-a számottevően - párjukkal azonos (55\%), vagy jelentósebb mértékben (23\%) -, illetve 17\% nem számottevő arányban járul hozzá. 5\%-uk vallotta azt, hogy egzisztenciájukat más személyek (pl. szülők) biztosítják.

\subsection{Vizsgálati eszközök}

Az Adatlap segítségével tájékozódtunk a vizsgálati személyek demográfiai és egyéb pszichoszociális jellemzőiről.

Az Intrauterin Kapcsolati Kérdőív (IUKK) tételeit gyakorlati munkatapasztalatok felhasználásával alakítottuk ki, várandóssokkal foglalkozó szakemberek bevonásával (várandós relaxáció, anya-magzat kapcsolatanalízis, 
dúla, ld. köszönetnyilvánítás). A kérdőív 28 tétellel, nyolc területet fed le: 1. Érzelmek, 2. Gondolatok, fantáziák, jellemzók tulajdonítása, 3. Magzathoz kapcsolódó tevékenységek, interakciók, 4. Szoptatási szándék, 5. Egészségmagatartás, 6. Anyai kompetencia, 7. Anyaszereppel való azonosulás és 8. Az élmények megosztása. Az egyes tételekkel való egyetértést egy 4-fokú Likert-típusú skálán lehet bejelölni a "tökéletesen igaz" (3), „többnyire igaz" (2), „kismértékben igaz” (1), „egyáltalán nem igaz” (0) válaszlehetőség valamelyikének megadásával. Hét tétel fordított. A kérdőíven összesen 84 pont érhető el. Minél magasabb a pontszám, annál intenzívebb kapcsolattal számolunk.

A Maternal Fetal Attachment Scale magyar változatát, az MFAS-HU-t használtuk (Andrek és mtsai, 2016), mivel eredetijét az MFAS-t (Cranley 1981), számos nyelvre fordították le, és nemzetközi vizsgálatokban mindmáig a leggyakrabban használt mérőeszköz (Alhusan, 2007; Beck, 1999). A kérdőív 24 tételét a vizsgálati személyeknek 5-fokú Likert-típusú skálán kell értékelnie: Az alábbiakat gondolom, teszem: „határozottan igen” (5), „igen” (4), „bizonytalan” (3), „,nem” (2), „,határozottan nem” (1). A skála a következő alskálákra bomlik: 1. Szerepvállalás, 2. Elkülönülés, 3. Interakció, 4. Attribúció és 5. Önfeladás. Az alskálákon elért magasabb pontszám erőteljesebb anyai bevonódást jelent az adott területen. A szerző (Cranley 1981) tapasztalatai és a későbbi nemzetközi tapasztalatok szerint az összpontszám jó reliabilitású (Cranley, 1992; Müller \& Ferketich, 1993), ugyanakkor az alskálák nem kellő mértékben megbízhatóak (Beck, 1999). A magyar változat pszichometriai jellemzói összhangban vannak a nemzetközi tapasztatokkal, azaz a Cronbach-alfa együttható az összpontszám tekintetében 0,87, míg az alskálák Cronbach-alfa értékei a következóképpen alakultak: Szerepvállalás: 0,74, Elkülönülés: 0,58, Interakció: 0,57, Attribúció: 0,65 és az Önfeladás: 0,65 (Andrek és mtsai, 2016; Andrek, Hadházi, \& Kekecs, 2016). A strukturális bizonytalanság miatt, tekintettel a skála széles körben való alkalmazására, az MFAS-HU összpontszámát használtuk.

A párkapcsolati intimitás mérését az Intimate Bond Measurement (IBM) elnevezésú, Wilhelm és Parker (1988) szerzőpáros által kidolgozott, önbeszámolón alapuló mérőeszközzel végeztük. Az intim kötődés mérésére alkalmas 24 tételes kérdőív 12-12 tétellel a "Gondoskodás” és a „Kontroll” dimenzióit tartalmazza. A Gondoskodás dimenzió érzelmi és fizikai gondoskodást fejez ki, melegséget, figyelmet, vonzalmat és baráti kapcsolatot. A Kontroll dimenzió dominanciát, tolakodást, kritikát, tekintélyelvú attitúdöt és viselkedést fed le. A válaszadás egy 4-fokú Likert-típusú skálán történik, a „tökéletesen igaz" (3), ,többnyire igaz” (2), ,kismértékben igaz” (1) és "egyáltalán nem igaz" (0) lehetőségek valamelyikének megjelölésével. A skálákon elért magas pontszám azt mutatja, hogy magasra értékeljük a párunk gondoskodó, illetve kontrolláló magatartását. A kérdőív magyar fordítása - Parker hozzájárulásával - Hadházi, Gérecz és Végh (2011) nevé- 
hez köthető, akik 455 fős magyar mintán magas teszt-reteszt reliabilitásról és jól elkülönülő alskálákról számoltak be. Leírták a párkapcsolati elégedettséggel, valamint a felnőtt kötődésnek a szorongás és elkerülés dimenzióival való összefüggéseit sine morbo és depressziós vizsgálati személyeknél (Gérecz \& Hadházi, 2014). A jelen vizsgálatban a kérdőív belső megbízhatósága igen jónak bizonyult: a Gondoskodás skála Cronbach-alfa értéke 0,91, a Kontroll skáláé 0,84 .

A szülői bánásmódot a Parental Bonding Instrument (PBI; Parker, Tulping \& Brown, 1979) magyar változatával (H-PBI; Tóth \& Gervai, 1999) mértük. A kérdőív 25 tételt tartalmaz külön-külön az édesanyára/nevelőanyára és édesapára/nevelőapára, és három faktort foglal magába, úgymint 1. „Szeretet”, 2. „Túlvédés”, 3. „Korlátozás”. A kérdőív egy 4-fokú Likert-típusú skálát használ. Válaszlehetőségek: „nagyon jellemző” (3), ,általában igaz” (2), "alig" (1), „egyáltalán nem igaz” (0). Az alskálákon elért magas pontszám intenzív szülői szeretetet, túlvédést és korlátozást jelez. Jelen vizsgálatban mindhárom alskála belső megbízhatósága magasnak bizonyult apánál és anyánál egyaránt, a Cronbach-alfa értékek 0,75 és 0,92 között mozogtak.

\subsection{Vizsgálati eljárás}

A kutatást engedélyezte a Károli Gáspár Református Egyetem Pszichológiai Intézetének Etikai Bizottsága (az etikai engedély száma: 389/2012/P). A vizsgálati személyek toborzására budapesti nőgyógyászati és védőnői gondozás során a védőnői rendelőkben és ultrahang-vizsgálati magánrendelőkben került sor, ahol a vizsgálatvezetők előzetes instrukcióinak megfelelően, az ott dolgozó védőnő és egészségügyi asszisztens személyesen szólította meg a várandós anyákat. A részvétel tájékoztatott beleegyezéssel, önkéntes és anonim módon, anyagi kompenzáció nélkül történt. Akik beleegyeztek a vizsgálatban való részvételbe, egy lezárt borítékban kapták meg a kitöltendő kérdőívcsomagot, amelyet a várakozási időben, a helyszínen tölthettek ki. Tapasztalataink szerint a kitöltés kb. 15 percet vett igénybe, nem volt olyan megkérdezett várandós, aki ne vállalta volna a részvételt. Amennyiben valaki nem jutott a kitöltés végére, a vizsgálatra való várakozás ideje alatt, a vizsgálat után befejezhette. Csupán 4 főt kellett kizárni hiányos kitöltés miatt. Az anyák nyugodt körülmények között dolgozhattak, maguk zárták le a borítékot és helyezték el a váróban kihelyezett gyújtődobozba, ami az anonimitást is garantálta számukra. Minimális torzító hatással, ez esetben is számolunk, ami a helyszín által is implikált elvárásnak való megfelelés érzése a kitöltés során. 


\subsection{Statisztikai elemzés}

Az alkalmazott kérdőívek belső megbízhatóságának ellenőrzésére Cronbachalfa mutatót számítottunk. Az IUKK kérdôív szerkezetét faktoranalízis vizsgálattal elemeztük Field (2013) és Costello \& Osborne (2005) ajánlásai alapján. Az explorátoros faktoranalízishez a normalitás sérülése miatt a főfaktor eljárást (principal axis factoring) alkalmaztuk, ferdeszögú forgatással (direct oblimin, Delta $=0$ ). A konfirmátoros faktoranalízist az R 3.02 programban végeztük a „SEM” (Structural Equation Modeling) csomaggal, amelynek során elóször az eredetileg feltételezett 8 faktoros, majd az explorátoros faktoranalízis során feltárt 3 faktoros modell illeszkedését teszteltük (Hooper, Coughlan, \& Mullen, 2008).

A kérdóíven szerzett pontszámok összefüggéseit az MFAS-HU értékeivel, demográfiai és más pszichoszociális tényezőkkel kategorikus független változóknál Mann-Whitney-féle U-próbával (2 csoport esetén) vagy Kruskal-Wallis-próbával (több csoport esetén) végeztük, folytonos független változók esetében pedig a Spearman-féle rangkorrelációs eljárást alkalmaztunk. A 10 fónél kisebb csoportokat nem elemeztük. Az elemzéseket az SPSS24 statisztikai programcsomaggal végeztük.

\section{Eredmények}

\subsection{Az Intrauterin Kapcsolati Kérdőív faktorstruktúrájának vizsgálata}

A konfirmátoros faktoranalízis eredményei azt mutatják, hogy a modell illeszkedési mutatói az elfogadhatósági határ körül mozognak. Az RMSEA =0,08 és $\chi^{2} / \mathrm{Df}=1,645$ értékek elfogadhatónak minősülnek, míg az NFI = 0,85 és $\mathrm{CFI}=0,87$ mutatók az elfogadhatósági határ alatt vannak.

Mivel a konfirmátoros faktorelemzés eredménye nem lett konkluzív, explorátoros faktorelemzést végeztünk, hogy meghatározzuk az ideális faktorstruktúrát és azonosítsuk az esetlegesen rosszul illeszkedő itemeket.

Az explorátoros faktoranalizis során az alacsony extrakció utáni kommunalitású $(<0,4)$ tételeket egyenként a legalacsonyabb kommunalitásútól kezdve kiejtettük, hogy elérjük a legalább 0,65-ös átlagos kommunalitást. Megvizsgáltuk a végleges tételegyüttest. A kiejtett tételek sorrendben az alábbiak voltak: 2, 27, 19, 11, 7, 26, 1, 15, 14, 12, 13, 9, 25, 10, 18, 23. Itt minden tételnek 0,5 feletti a kommunalitása, és az átlagos kommunalitás 0,65. Ekkor 3 faktor alakult ki, úgymint 1 . Megfelelés az elvárt anyai magatartásnak (5 tétel, megmagyarázott variancia: $58.86 \%$ ); 2. Pozitív érzelmi bevonódás nehézsége (5 tétel, megmagyarázott variancia: 8.15\%), 3. Egészségmagatartás (2 tétel, megmagyarázott variancia: 7.32\%). A „Megfelelés az elvárt 
anyai magatartásnak" faktor azt ragadja meg, hogy mennyire felel meg a várandós a társadalmunkban gyakorta elvártnak tekintett magatartási és viszonyulási formáknak, amelyekkel a kismamák szembesülhetnek a hétköznapokban, sőt a várandósgondozás során is. A „Pozitív érzelmi bevonódás nehézsége" faktor a magzathoz, illetve a várandóssághoz fúződő pozitív érzelmek kifejezésének, és a magzat érzelmi elfogadására utaló viselkedésnek a korlátait testesíti meg. Az „Egészségmagatartás” faktor pedig a magzat egészséges fejlődése érdekében az anyában kialakuló egészségtámogató attitúdöt jelöli. Láthatjuk, hogy ez utóbbi, a 3. alskála mindkét tétele erősen tölt a másik két faktorra is, ezért nem jelenthetjük ki, hogy ezek az itemek csak az adott, 3. faktorba tartozhatnak. S mivel csak két tételt tartalmaz, instabilnak tekinthető, de a vele kapott elemzéseket is közzétesszük, mert a jelenlegi itemstruktúrával elért eredmények segíthetnek más kutatóknak a skála továbbfejlesztésében. Az 1. táblázat szemlélteti a struktúra mátrixot és a faktorok korrelációs mátrixát.

1. táblázat. Az Intrauterin Kapcsolati Kérdőív struktúra mátrixa és a faktorok közötti korrelációs együtthatók

\begin{tabular}{|l|c|c|c|}
\hline \multicolumn{1}{|c|}{ Az IUKK tételei } & \multicolumn{2}{c|}{ Faktorok } \\
\cline { 2 - 4 } & $\begin{array}{c}\text { Megfelelés } \\
\text { az elvárt } \\
\text { anyai maga- } \\
\text { tartásnak }\end{array}$ & $\begin{array}{c}\text { Pozitív } \\
\text { érzelmi } \\
\text { bevonódás } \\
\text { nehézsége }\end{array}$ & $\begin{array}{c}\text { Egészség- } \\
\text { magatartás }\end{array}$ \\
\hline $\begin{array}{l}\text { 17. Gyakran az jár az eszemben, hogy } \\
\text { vajon mit csinálhat a kisbabám. }\end{array}$ & $\mathbf{0 , 8 3}$ & $-0,57$ & 0,25 \\
\hline $\begin{array}{l}\text { 5. Már most erófeszítéseket teszek azért, } \\
\text { hogy jó anya legyek. }\end{array}$ & $\mathbf{0 , 8}$ & $-0,61$ & 0,28 \\
\hline $\begin{array}{l}\text { 16. Szeretnék minél tájékozottabb lenni } \\
\text { az anyasággal kapcsolatban. }\end{array}$ & $\mathbf{0 , 7 9}$ & $-0,62$ & 0,29 \\
\hline 8. Élvezem ezt az állapotot. & $\mathbf{0 , 7 6}$ & $-0,63$ & 0,34 \\
\hline $\begin{array}{l}\text { 22. Igyekszem minél tájékozottabb lenni } \\
\text { a kisbabám állapotával kapcsolatban. }\end{array}$ & $\mathbf{0 , 7 2}$ & $-0,63$ & 0,32 \\
\hline 4. Jó érzés a kisbabámra gondolni. & 0,69 & $\mathbf{- 0 , 9 3}$ & 0,31 \\
\hline $\begin{array}{l}\text { 28. Úgy érzem, hogy a lehetó legjobb } \\
\text { helyen van nálam ez a baba. }\end{array}$ & 0,6 & $\mathbf{- 0 , 8 1}$ & 0,28 \\
\hline $\begin{array}{l}\text { 24. Örömmel töltött el a várandósságom } \\
\text { híre. }\end{array}$ & 0,62 & $\mathbf{- 0 , 8 1}$ & 0,37 \\
\hline $\begin{array}{l}\text { 6. Szívesen megosztom a várandóssággal } \\
\text { kapcsolatos élményeimet. }\end{array}$ & 0,7 & $\mathbf{- 0 , 7 4}$ & 0,19 \\
\hline
\end{tabular}




\begin{tabular}{|l|c|c|c|}
\hline $\begin{array}{l}\text { 21. Nem beszélek szívesen a babámmal } \\
\text { kapcsolatos érzéseimről. }\end{array}$ & $-0,60$ & $\mathbf{0 , 7 2}$ & $-0,13$ \\
\hline $\begin{array}{l}\text { 3. Jobban odafigyelek magamra, amióta } \\
\text { babát várok. }\end{array}$ & 0,54 & $-0,72$ & $\mathbf{0 , 7 7}$ \\
\hline $\begin{array}{l}\text { 20. Több figyelmet fordítok az } \\
\text { egészségemre, mióta várandós vagyok. }\end{array}$ & 0,61 & $-0,45$ & $\mathbf{0 , 7 6}$ \\
\hline Korrelációs együtthatók & 1,00 & $-0,73^{* *}$ & $0,33^{* *}$ \\
\hline Megfelelés az elvárt anyai magatartásnak & $-0,73^{* *}$ & 1,00 & $-0,32^{* *}$ \\
\hline Pozitív érzelmi bevonódás nehézsége & $0,33^{* *}$ & $-0,32^{* *}$ & 1,00 \\
\hline Egészségmagatartás & &
\end{tabular}

Megjegyzés: ** $p<0,01$.

A fenti elemzés egy új modell kialakítására adott lehetóséget, amivel az IUKK-Rövidített (IUKK-R), 12 tételes változata jött létre.

\subsection{Reliabilitásvizsgálat}

Az IUKK-R alskálák belső megbízhatóságának vizsgálatát elvégezve, a Cronbach-alfa értékek igen magas belső megbízhatóságot mutatnak: 1. Megfelelés az elvárt anyai magatartásnak: 0,89; 2. Pozitív érzelmi bevonódás nehézsége: 0,90; 3. Egészségmagatartás: 0,81; a teljes kérdőíven elért pontok összege, azaz, a kötődés intenzitására utaló összpontszám esetében: 0,93. Az alábbiakban csak az IUKK-R-rel kapott elemzések eredményeit mutatjuk be.

\subsection{Normalitásvizsgálat}

A csúcsosság és ferdeség mutatók alapján a normalitás feltétele nem sérül számottevően a legtöbb skála esetében. A Pozitív érzelmi bevonódás nehézsége alskálánál az alacsony értékek vannak túlsúlyban (ferdeség = -1,51). A többi alskála esetén viszont a ferdeség és csúcsosság az elfogadható határértékek, -1 és 1 között találhatók. Az eloszlási ábrák tanulmányozása alapján szintén az látható, hogy a skálák többsége enyhe negatív ferdeséget mutat. 


\subsection{A kérdőív validitásának vizsgálata}

A külső validitás ellenőrzésére összevetettük az IUKK-R-t az MFAS-HU összpontszámával, és alskáláival. A nemzetközi szakirodalommal összhangban, az MFAS-HU alskálái nem bizonyultak eléggé megbízhatónak, a Cronbach-alfa értékek a következőképpen alakultak: összes (24) tétel: 0,87; Szerepvállalás (4 tétel): 0,74; Elkülönülés (4 tétel): 0,58; Interakció ( 5 tétel): 0,57; Attribúció (6 tétel): 0,65 és Önfeladás (5 tétel): 0,64. A külföldi szakirodalmi ajánlásoknak megfelelően (Beck, 1999; Busonera, Cataudella, Lampis, Tommasi \& Zavattini, 2016; Cranley, 1992; Müller \& Ferketich, 1993) csak az összpontszámmal való összefüggéseket tekintjük mérvadónak.

Hipotézisünknek megfelelóen erős együttjárás mutatkozik az IUKK-R és az MFAS-HU összpontszámai között, illetve az IUKK-R Megfelelés az elvárt anyai magatartásnak alskálája és az MFAS-HU összpontszáma között. Ez utóbbival mérsékelt erősségú kapcsolatot mértünk a Pozitív érzelmi bevonódás nehézsége és az Egészségmagatartás alskálákkal is (2. táblázat). Ezek az eredmények arra utalnak, hogy az IUKK-R az MFAS-HU-hoz hasonló konstruktumot mér, de a két skála nem mutat teljes egyezést, ami arra utal, hogy az anya-magzat kapcsolatnak a két skála által megragadott dimenziói nem teljesen átfedőek.

2. táblázat. Az IUKK-R külső validitásvizsgálatának eredményei

\begin{tabular}{|l|c|c|c|c|}
\hline & $\begin{array}{c}\text { IUKK-R } \\
\text { összpont- } \\
\text { szám }\end{array}$ & $\begin{array}{c}\mathbf{1 .} \\
\text { Megfelelés } \\
\text { az elvárt anyai } \\
\text { magatartásnak }\end{array}$ & $\begin{array}{c}\mathbf{2 .} \\
\text { Pozitív érzelmi } \\
\text { bevonódás } \\
\text { nehézsége }\end{array}$ & $\begin{array}{c}\text { 3. } \\
\text { Egészség- } \\
\text { magatartás }\end{array}$ \\
\hline $\begin{array}{l}\text { MFAS-HU } \\
\text { összpontszám }\end{array}$ & $\mathbf{0 , 6 2 ^ { * * }}$ & $\mathbf{0 , 6 0 ^ { * * }}$ & $-\mathbf{- 0 , 4 9 * *}$ & $\mathbf{0 , 4 4 ^ { * * }}$ \\
\hline Szerepvállalás & $0,53^{* *}$ & $0,47^{* *}$ & $-0,5^{* *}$ & $0,38^{* *}$ \\
\hline Elkülönülés & $0,46^{* *}$ & $0,41^{* *}$ & $-0,41^{* *}$ & $0,32^{* *}$ \\
\hline Interakció & $0,28^{* *}$ & $0,30^{* *}$ & $-0,21^{*}$ & 0,10 \\
\hline Attribúció & $0,46^{* *}$ & $0,47^{* *}$ & $-0,35^{* *}$ & $0,29^{* *}$ \\
\hline Önfeladás & $0,69^{* *}$ & $0,63^{* *}$ & $-0,52^{* *}$ & $0,65^{* *}$ \\
\hline
\end{tabular}

Megjegyzés: ** $p<0,01$. 


\subsection{Az Intrauterin Kapcsolati Kérdőív Rövid változatának összefüggései néhány szociodemográfiai tényezővel}

A vizsgálati személyek családi állapotáról megállapítható, hogy közel 63\% házasságban, míg 37\% élettársi kapcsolatban él a gyermek apjával. Ebben az elemzésben nem szerepelnek azok, akik külön élnek és akik soha nem éltek együtt, mert mindkét kategóriából csak 2-2 személy van a mintában. Így 110 fővel végeztük el az elemzéseket. Eredményeink szerint az IUKK-R faktorait nézve, akik házasságban élnek a magzatuk apjával, azoknak magasabb az összpontszámuk és a Megfelelés az elvárt anyai magatartásnak skálán elért pontszámuk, valamint alacsonyabb a Pozitív érzelmi bevonódás nehézsége skálán elért pontjuk, mint azoknak, akik élettársi kapcsolatban élnek. Az Egészségmagatartást nem befolyásolta szignifikánsan a családi állapot.

Elemzésünk szerint a család anyagi bevétele nem mutat kapcsolatot az IUKK-R-rel, míg minél nagyobb az édesanya anyagi hozzájárulása, annál magasabb az összpontszám és az Egészségmagatartás.

Mintánkban főként magasabb iskolai végzettségü édesanyák kerültek szándékunk ellenére, ami részben az adatgyújtés módjának is köszönhető, hisz valószínúsítjük, hogy magasabb szocioökonómiai státuszú várandósok látogatták az adott rendelőket és vállalták szívesen a vizsgálatban való részvételt. Az iskolázottság szerint képzett csoportok létszáma kiegyenlítetlennek bizonyult, így az alacsony csoportlétszámok miatt csak a szakközép/ gimnázium (20 fó), és az a feletti végzettségúeknél (87 fő) elemeztük az iskolázottság hatását az anya-magzat kapcsolatra. Összességében az iskolai végzettség nem bizonyult meghatározó bejósló faktornak, mivel az IUKK-R alskáláit egyáltalán nem befolyásolta a végzettség. Az eredményeket a 3. táblázatban részletezzük.

Végül az életkor nem bizonyult jelentős befolyásoló tényezőnek az anyamagzat kapcsolatot illetően, nincs szignifikáns lineáris összefüggésben az IUKK-R-rel, a korrelációs együtthatók értékei a -0,16 és 0,04 közötti tartományban helyezkedtek el. 
3. táblázat. Az IUKK-R pontszámok összefüggése néhány szociodemográfiai tényezővel

\begin{tabular}{|c|c|c|c|c|c|}
\hline \multirow[t]{2}{*}{ Változók } & $n$ & $\begin{array}{l}\text { IUKK-R } \\
\text { összpont- } \\
\text { szám }\end{array}$ & $\begin{array}{l}\text { 1. Megfelelés } \\
\text { az elvárt } \\
\text { anyai maga- } \\
\text { tartásnak }\end{array}$ & $\begin{array}{l}\text { 2. Pozitív } \\
\text { érzelmi } \\
\text { bevonódás } \\
\text { nehézsége }\end{array}$ & $\begin{array}{l}\text { 3. Egészség- } \\
\text { magatartás }\end{array}$ \\
\hline & & \multicolumn{4}{|c|}{ medián (minimum - maximum) } \\
\hline \multicolumn{6}{|l|}{ Családi állapot } \\
\hline házasság & 69 & $2,75(0,92-3)$ & $2,8(0,8-3)$ & $0,2(0-2,2)$ & $3(1-3)$ \\
\hline élettársi kapcsolat & 41 & $2,5(1,08-3)$ & $2,4(0,8-3)$ & $0,4(0-2,2)$ & $2,5(0,5-3)$ \\
\hline Mann-Whitney $U$ & & 1031,500 & 1035,500 & 1106,000 & 1219,500 \\
\hline Wilcoxon $W$ & & 1892,500 & 1896,500 & 3521,000 & 2080,500 \\
\hline Z & & $-2,378$ & $-2,374$ & $-1,960$ & $-1,284$ \\
\hline p-érték & & 0,017 & 0,018 & 0,050 & 0,199 \\
\hline \multicolumn{6}{|l|}{ Iskolázottság } \\
\hline $\begin{array}{l}\text { szakközép/ } \\
\text { gimnázium }\end{array}$ & 20 & $2,29(1,08-3)$ & $2,5(0,8-3)$ & $0,4(0-2)$ & $2,5(1-3)$ \\
\hline $\begin{array}{r}\text { főisk./egyet. } \\
\text { hallgató }\end{array}$ & 14 & $2,46(1,42-3)$ & $2,5(1,2-3)$ & $0,6(0-1,4)$ & $2,5(1,5-3)$ \\
\hline főiskola, egyetem & 73 & $2,67(0,92-3)$ & $2,6(0,8-3)$ & $0,2(0-2,2)$ & $3(0,5-3)$ \\
\hline$\chi^{2}(\mathrm{df})$ & & $3,061(2)$ & $2,612(2)$ & $4,496(2)$ & $2,110(2)$ \\
\hline$p$-érték & & 0,216 & 0,271 & 0,106 & 0,348 \\
\hline \multicolumn{6}{|l|}{ Anyagi hozzájárulás } \\
\hline nagyban & 26 & $2,83(2-3)$ & $2,8(1,6-3)$ & $0,2(0-0,8)$ & $3(1,5-3)$ \\
\hline azonos mértékben & 63 & $2,58(0.92-3)$ & $2,6(1-3)$ & $0,4(0-2,2)$ & $2,5(1-3)$ \\
\hline nem számottevően & 19 & $2,5(1-3)$ & $2,2(0,8-3)$ & $0,2(0-2,2)$ & $2,5(0,5-3)$ \\
\hline $\begin{array}{r}\text { más személyek } \\
\text { (pl. szülők) } \\
\text { biztosítják }\end{array}$ & 5 & $2,67(1,17-3)$ & $2,4(1-3)$ & $0,2(0-1,8)$ & $2,5(1-3)$ \\
\hline$x^{2}(\mathrm{df})$ & & $8,541(3)$ & $7,359(3)$ & $3,851(3)$ & $8,707(3)$ \\
\hline$p$-érték & & 0,036 & 0,061 & 0,278 & 0,033 \\
\hline
\end{tabular}




\subsection{Az Intrauterin Kapcsolati Kérdőív \\ rövid változatának összefüggése a várandóssággal \\ és fogantatással kapcsolatos tényezőkkel}

Elsőként a várandósság idejét, mint lehetséges prediktort vizsgáltuk, de eredményeink szerint, az IUKK-R alskálák egyike sem korrelált szignifikánsan a várandósság korával $\left(r_{s}=-0,11-0,08\right)$.

Mintánk a várandósság tervezettsége tekintetében, a magas iskolázottság és kedvező szocioökonómiai státusz ellenére, igen megosztott volt: 46\%-a az anyáknak válaszolta azt, hogy a jelen terhessége tervezett, $42 \%$ nem tervezte, $12 \%$ akik nem mostanra tervezték a kisbabát. A várandósság tervezettsége és a fogantatás módja (természetes, vagy orvosi segítséggel történő) nem mutatott szignifikáns összefüggést az anya-magzat kötődéssel.

A testvérek, korábbi gyermekek szerepét vizsgálva megállapítható, hogy a vizsgálati személyek nagy részének (69\%) nincsen a magzaton kívül más gyermeke, egyharmadának (31\%) viszont van (1-3) gyermeke, de a gyermekek számának nem volt kimutatható szerepe a magzathoz való viszonyulásban.

A veszteségek hatását nézve a magzati kötődésre, az alábbiakra derült fény. Mintánk 15\%-a vallotta azt, hogy előfordult már vetélés az életében. Azok az anyák, akiknek volt korábban spontán vetélésük, alacsonyabb értékkel jellemezhetóek az IUKK-R összpontszámon, a Megfelelés az elvárt anyai magatartásnak skálán, mint a vetélést át nem élt társaik. A válaszadók $11 \%$-a nyilatkozta azt, hogy volt müvi terhességmegszakítása, de egyetlen kötődési mutatóval sem találtunk kapcsolatot. Mivel kevés olyan személy volt a mintában, akinek egynél több vesztesége volt, egy csoportként kezeltünk mindenkit, akinek volt már korábbi vesztesége (31\%-a a teljes mintának), és őket hasonlítottuk azokhoz, akiknek nem volt. Egyik IUKK-R faktorral sem mutatott összefüggést a veszteségek megtapasztalása.

Az anya saját születésének körülményeit vizsgálva, mivel kevés volt a koraszülött és más születési módot megjelölő személy, ezért csak az időre születetteket vettük figyelembe. Összehasonlítottuk az időre természetes módon születetteket azokkal, akik időre, de valamilyen beavatkozás segítségével jöttek a világra (pl. császármetszéssel, epidurális vagy más gyógyszeres fájdalomcsillapítás mellett, esetleg múszeres befejezéssel). A saját születés módja komoly meghatározó tényezónek túnik a magzati kötődésben az anyáknál: minden IUKK-R faktor szignifikánsan összefügg ezzel a változóval. A természetes úton születettek esetében magasabb kötődés összpontszámokról és alacsonyabb Pozitív érzelmi bevonódás nehezítettségéról beszélhetünk, mint a múvi beavatkozással világra hozott nők esetében. 
A magzatmozgás érzékelésének a hatását vizsgálva, mivel kevesen voltak azok, akik nem biztosan érzik a magzat mozgását és akik nem érzik, ezért ezt a két csoportot összevontuk (összesen 14 fó) és őket hasonlítottuk össze azokkal, akik biztosan érzik már a magzat mozgását (99 fó). Azok az anyák, akik biztosan érzik a magzat mozgását és azok, akik nem, vagy nem biztosan érzik, nem különböztek egyik alskálában sem. Az eredményeket a 4. táblázatban mutatjuk be részletesen.

4. táblázat. Az IUKK-R pontszámok összefüggése néhány várandóssággal és fogantatással kapcsolatos tényezővel

\begin{tabular}{|c|c|c|c|c|c|}
\hline \multirow[t]{2}{*}{ Változók } & $n$ & $\begin{array}{c}\text { IUKK-R } \\
\text { összpontszám }\end{array}$ & $\begin{array}{l}\text { 1. Megfelelés } \\
\text { az elvárt } \\
\text { anyai maga- } \\
\text { tartásnak }\end{array}$ & $\begin{array}{l}\text { 2. Pozitív } \\
\text { érzelmi } \\
\text { bevonódás } \\
\text { nehézsége }\end{array}$ & $\begin{array}{c}3 . \\
\text { Egészség- } \\
\text { maga- } \\
\text { tartás }\end{array}$ \\
\hline & & \multicolumn{4}{|c|}{ medián (minimum - maximum) } \\
\hline \multicolumn{6}{|c|}{ A várandósság tervezettsége } \\
\hline tervezett & 52 & $2,75(1,08-3)$ & $2,6(0,8-3)$ & $0,2(0-1,6)$ & $3(1-3)$ \\
\hline nem tervezett & 48 & $2,58(0,92-3)$ & $2,5(1-3)$ & $0,4(0-2,2)$ & $2,5(1-3)$ \\
\hline $\begin{array}{r}\text { tervezett, de nem } \\
\text { mostanra }\end{array}$ & 14 & $2,5(1,25-3)$ & $2,4(1,2-3)$ & $0,2(0-2)$ & $2,5(0,5-3)$ \\
\hline$x^{2}(\mathrm{df})$ & & $3,178(2)$ & $1,593(2)$ & $4,264(2)$ & $1,636(2)$ \\
\hline$p$-érték & & 0,204 & 0,451 & 0,119 & 0,441 \\
\hline \multicolumn{6}{|c|}{ A fogantatás módja } \\
\hline $\begin{array}{r}\text { váratlanul, } \\
\text { természetesen }\end{array}$ & 35 & $2,58(1,17-3)$ & $2,4(0,8-3)$ & $0,2(0-2)$ & $3(1-3)$ \\
\hline $\begin{array}{r}\text { tervezetten, } \\
\text { természetesen }\end{array}$ & 69 & $2,67(0,92-3)$ & $2,6(0,8-3)$ & $0,2(0-2,2)$ & $2,5(1-3)$ \\
\hline $\begin{array}{r}\text { tervezetten, } \\
\text { orvosi segítséggel }\end{array}$ & 10 & $2,5(1,67-3)$ & $2,6(1,6-3)$ & $0,3(0-1,4)$ & $\begin{array}{c}2,25(0,5- \\
3)\end{array}$ \\
\hline$x^{2}(\mathrm{df})$ & & $0,005(2)$ & $0,684(2)$ & $0,169(2)$ & $1,635(2)$ \\
\hline$p$-érték & & 0,997 & 0,710 & 0,919 & 0,442 \\
\hline \multicolumn{6}{|c|}{ A testvérek, korábbi gyermekek szerepe } \\
\hline nincs & 79 & $2,67(0,92-3)$ & $2,6(0,8-3)$ & $0,2(0-2,2)$ & $2,5(0,5-3)$ \\
\hline van & 35 & $2,67(0,92-3)$ & $2,6(0,8-3)$ & $0,2(0-2,2)$ & $2,5(1-3)$ \\
\hline Mann-Whitney $U$ & & 1325,000 & 1230,500 & 1348,000 & 1365,000 \\
\hline Wilcoxon $W$ & & 1365,000 & 1860,500 & 1978,000 & 4525,000 \\
\hline
\end{tabular}


4. táblázat. (Folytatás.)

\begin{tabular}{|c|c|c|c|c|c|}
\hline Változók & $n$ & $\begin{array}{c}\text { IUKK-R } \\
\text { összpontszám }\end{array}$ & $\begin{array}{l}\text { 1. Megfelelés } \\
\text { az elvárt } \\
\text { anyai maga- } \\
\text { tartásnak }\end{array}$ & $\begin{array}{l}\text { 2. Pozitív } \\
\text { érzelmi } \\
\text { bevonódás } \\
\text { nehézsége }\end{array}$ & $\begin{array}{c}3 . \\
\text { Egészség- } \\
\text { maga- } \\
\text { tartás }\end{array}$ \\
\hline & & \multicolumn{4}{|c|}{ medián (minimum - maximum) } \\
\hline$Z$ & & $-0,355$ & $-0,946$ & $-0,218$ & $-0,115$ \\
\hline$p$-érték & & 0,723 & 0,344 & 0,828 & 0,909 \\
\hline \multicolumn{6}{|l|}{ Vetélés } \\
\hline nem történt & 97 & $2,67(0,92-3)$ & $2,6(0,8-3)$ & $0,2(0-2,2)$ & $3(0,5-3)$ \\
\hline történt & 17 & $2,25(1-3)$ & $1,8(1-3)$ & $0,6(0-2,2)$ & $2,5(1-3)$ \\
\hline Mann-Whitney $U$ & & 549,000 & 519,500 & 586,500 & 614,500 \\
\hline Wilcoxon $W$ & & 702,000 & 672,500 & 5339,500 & 767,500 \\
\hline$Z$ & & $-2,201$ & $-2,457$ & $-1,946$ & $-1,780$ \\
\hline$p$-érték & & 0,028 & 0,014 & 0,052 & 0,075 \\
\hline \multicolumn{6}{|l|}{ Abortusz } \\
\hline nem történt & 101 & $2,67(0,92-3)$ & $2,6(0,8-3)$ & $0,2(0-2,2)$ & $2,5(0,5-3)$ \\
\hline történt & 13 & $2,67(1,58-3)$ & $2,4(1,6-3)$ & $0,2(0-1,6)$ & $3(1,5-3)$ \\
\hline Mann-Whitney $U$ & & 653,000 & 629,500 & 593,500 & 569,500 \\
\hline Wilcoxon $W$ & & 5804,000 & 720,500 & 684,500 & 5720,500 \\
\hline$Z$ & & $-0,031$ & $-0,244$ & $-0,577$ & $-0,826$ \\
\hline$p$-érték & & 0,975 & 0,807 & 0,564 & 0,409 \\
\hline \multicolumn{6}{|c|}{ Bármilyen veszteség } \\
\hline nem volt & 79 & $2,67(0,92-3)$ & $2,5(0,8-3)$ & $0,2(0-2,2)$ & $3(0,5-3)$ \\
\hline volt & 35 & $2,5(1-3)$ & $2,4(1-3)$ & $0,2(0-2,2)$ & $2,5(1-3)$ \\
\hline Mann-Whitney $U$ & & 1152,500 & 1110,500 & 1218,000 & 1255,500 \\
\hline Wilcoxon $W$ & & 1782,500 & 1740,500 & 4378,000 & 1885,500 \\
\hline$Z$ & & $-1,419$ & $-1,692$ & $-1,039$ & $-0,831$ \\
\hline$p$-érték & & 0,156 & 0,091 & 0,299 & 0,406 \\
\hline \multicolumn{6}{|c|}{ Saját születés körülményei } \\
\hline $\begin{array}{r}\text { időre } \\
\text { természetesen }\end{array}$ & 77 & $2,75(0,92-3)$ & $2,6(1-3)$ & $0,2(0-2,2)$ & $3(0,5-3)$ \\
\hline $\begin{array}{r}\text { időre } \\
\text { beavatkozással }\end{array}$ & 16 & $2,21(1,08-2,92)$ & $2,2(0,8-3)$ & $0,7(0-1,6)$ & $2,5(1-3)$ \\
\hline
\end{tabular}


4. táblázat. (Folytatás.)

\begin{tabular}{|c|c|c|c|c|c|}
\hline \multirow[t]{2}{*}{ Változók } & $n$ & $\begin{array}{c}\text { IUKK-R } \\
\text { összpontszám }\end{array}$ & $\begin{array}{l}\text { 1. Megfelelés } \\
\text { az elvárt } \\
\text { anyai maga- } \\
\text { tartásnak }\end{array}$ & $\begin{array}{l}\text { 2. Pozitív } \\
\text { érzelmi } \\
\text { bevonódás } \\
\text { nehézsége }\end{array}$ & $\begin{array}{c}3 . \\
\text { Egészség- } \\
\text { maga- } \\
\text { tartás }\end{array}$ \\
\hline & & \multicolumn{4}{|c|}{ medián (minimum - maximum) } \\
\hline Mann-Whitney $U$ & & 368,000 & 394,000 & 331,500 & 490,500 \\
\hline Wilcoxon $W$ & & 504,000 & 530,000 & 3334,500 & 626,500 \\
\hline Z & & $-2,538$ & $-2,293$ & $-2,998$ & $-1,391$ \\
\hline$p$-érték & & 0,011 & 0,022 & 0,003 & 0,164 \\
\hline \multicolumn{6}{|c|}{ Magzatmozgás érzékelése } \\
\hline igen & 99 & $2,67(0,92-3)$ & $2,6(0,8-3)$ & $0,2(0-2,2)$ & $2,5(0,5-3)$ \\
\hline $\begin{array}{r}\text { nem, vagy nem } \\
\text { biztosan }\end{array}$ & 14 & $2,67(1,08-3)$ & $2,8(0,8-3)$ & $0,2(0-1,6)$ & $3(1-3)$ \\
\hline Mann-Whitney $U$ & & 613,500 & 592,500 & 680,500 & 540,000 \\
\hline Wilcoxon $W$ & & 5563,500 & 5542,500 & 785,500 & 5490,000 \\
\hline Z & & $-0,696$ & $-0,887$ & $-0,112$ & $-1,418$ \\
\hline$p$-érték & & 0,487 & 0,375 & 0,911 & 0,156 \\
\hline
\end{tabular}

A magzat nemének ismerete fontos prediktora a magzati kötődésnek: azok, akik biztosan tudják, és akik biztosan nem tudják a magzat nemét, azok egyaránt magasabb pontszámokat kapnak a kötődés skálákon (és alacsonyabbat a Pozitív érzelmi bevonódás nehézsége skálán), mint azok, akik lehet, hogy tudják, de nem biztosak benne (5. táblázat).

Megvizsgáltuk, hogy az anya származási családjában a szülők családi állapota, mint az elsődleges szocializációs színteret meghatározó tényező, mutat-e összefüggést az anya-magzat kapcsolattal. A kis elemszám miatt összevontuk azt a csoportot, akiknek az édesanyjuk, és akiknek az édesapjuk meghalt, és ezt hasonlítottuk össze azokkal, akiknek együtt élnek, illetve akiknek elváltak a szüleik. Eredményeink szerint nem mutatható ki szignifikáns összefüggés a magzathoz való kötődés és anya szüleinek (családi) állapota között (6. táblázat). 
5. táblázat. A magzat nemének ismerete és a magzati kötődés szignifikáns összefüggései (Kruskal-Wallis-teszt)

\begin{tabular}{|r|c|c|c|c|c|}
\hline \multirow{2}{*}{$\begin{array}{c}\text { Tudja-e } \\
\text { a magzat } \\
\text { nemét? }\end{array}$} & $n$ & $\begin{array}{c}\text { IUKK-R } \\
\text { összpont- } \\
\text { szám }\end{array}$ & $\begin{array}{c}\text { 1. Megfelelés } \\
\text { az elvárt anyai } \\
\text { magatartásnak }\end{array}$ & $\begin{array}{c}\text { 2. Pozitív érzelmi } \\
\text { bevonódás } \\
\text { nehézsége }\end{array}$ & $\begin{array}{c}\text { 3. Egészség- } \\
\text { magatartás }\end{array}$ \\
\cline { 3 - 6 } igen & 80 & $2,71(0,92-3)$ & $2,6(0,8-3)$ & $0,2(0-2,2)$ & $3(0,5-3)$ \\
\hline $\begin{array}{r}\text { lehet, nem } \\
\text { biztos }\end{array}$ & 18 & $\begin{array}{c}1,78(1,17- \\
2,92)\end{array}$ & $1,6(1-2,8)$ & $1,3(0-2)$ & $2(1-3)$ \\
\hline nem & 15 & $2,67(1,92-3)$ & $2,8(0,8-3)$ & $0,2(0-1,2)$ & $2,5(2-3)$ \\
\hline$x^{2}(\mathrm{df})$ & & $14,522(2)$ & $13,230(2)$ & $15,557(2)$ & $5,895(2)$ \\
\hline$p$-érték & & 0,001 & 0,001 & $<0,001$ & 0,052 \\
\hline
\end{tabular}

6. táblázat. Az anya szüleinek családi állapota és a magzatával való kapcsolat összefüggéseinek vizsgálata (Kruskal-Wallis-teszt)

\begin{tabular}{|r|c|c|c|c|c|}
\hline \multirow{2}{*}{$\begin{array}{c}\text { A szülóḱ } \\
\text { családi } \\
\text { állapota }\end{array}$} & $n$ & $\begin{array}{c}\text { IUKK-R } \\
\text { összpont- } \\
\text { szám }\end{array}$ & $\begin{array}{c}\text { 1. Megfelelés } \\
\text { az elvárt anyai } \\
\text { magatartásnak }\end{array}$ & $\begin{array}{c}\text { 2. Pozitív érzelmi } \\
\text { bevonódás } \\
\text { nehézsége }\end{array}$ & $\begin{array}{c}\text { 3. Egészség- } \\
\text { magatartás }\end{array}$ \\
\cline { 2 - 6 } & & \multicolumn{5}{|c|}{ medián (minimum - maximum) } \\
\hline együtt élnek & 70 & $2,67(0,92-3)$ & $2,6(0,8-3)$ & $0,2(0-2,2)$ & $3(1-3)$ \\
\hline elváltak & 22 & $2,42(1,08-3)$ & $2,3(0,8-3)$ & $0,4(0-2)$ & $2,25(0,5-3)$ \\
\hline $\begin{array}{r}\text { valamelyikük } \\
\text { meghalt }\end{array}$ & 18 & $2,5(0,92-3)$ & $2,4(1-3)$ & $0,3(0-2,2)$ & $2,5(1-3)$ \\
\hline$x^{2}(\mathrm{df})$ & & $3,368(2)$ & $4,935(2)$ & $2,294(2)$ & $4,329(2)$ \\
\hline$p$-érték & & 0,186 & 0,085 & 0,318 & 0,115 \\
\hline
\end{tabular}

\subsection{Az Intrauterin Kapcsolati Kérdőív Rövid változatának összefüggése az észlelt párkapcsolati intimitással}

Az IBM Gondoskodás faktora minden IUKK-R alskálával és az összpontszámmal is szignifikánsan, mérsékelt erősséggel, illetve erősen korrelál. A korreláció pozitív, kivéve a Pozitív érzelmi bevonódás nehézsége esetében, ahol negatív irányú. 
A Kontroll skálával kevesebb a kapcsolat. Az IUKK-R összpontszámával gyenge, negatív irányú korrelációt mutat az IBM kontroll faktora és pozitív, mérsékelt erősségú együttjárást találunk az IUKK-R Pozitív érzelmi bevonódás nehézsége faktorával. Az eredményeket a 7. táblázatban részletezzük.

\subsection{Az Intrauterin Kapcsolati Kérdőív Rövid változatának összefüggése az anya szülői bánásmódjával}

A szülői bánásmód és a magzati kötődés kapcsolatáról összességében elmondhatjuk, hogy az anyai és az apai szeretet a legfontosabb determinánsok. Az anyai szeretet az IUKK-R összpontszámával és az alskáláival mérsékelt erősségú lineáris kapcsolatot mutatott, amelyek iránya a pozitív érzelmi bevonódás nehézsége kivételével pozitív. Az apai szeretet esetében az összefüggések ugyancsak szignifikánsak, irányuk megfelel az anyai szeretettel kapott mintázatnak, ugyanakkor erősségük a pozitív érzelmi bevonódás nehézségével mutatkozó mérsékelt erősségú kapcsolat kivételével gyenge. A szülői bánásmód többi dimenziója közül egyedül az apai túlvédés mutatott szignifikáns, azonban gyenge kapcsolatot a magzati kötődéssel. Az összefüggések iránya az IUKK-R összpontszáma és az egészségmagatartás esetében negatív, míg a pozitív érzelmi bevonódás nehézsége esetében pozitív (ld. 7. táblázat).

7. táblázat. A magazattal való kapcsolat (IUKK-R) és az anya néhány

pszichoszociális jellemzője összefüggéseinek vizsgálata (korrelációs elemzés)

\begin{tabular}{|l|l|c|c|c|c|}
\hline \multicolumn{2}{|c|}{ Skálák } & $\begin{array}{c}\text { IUKK-R } \\
\text { össz- } \\
\text { pont- } \\
\text { szám }\end{array}$ & $\begin{array}{c}\text { 1. Megfelelés } \\
\text { az elvárt } \\
\text { anyai maga- } \\
\text { tartásnak }\end{array}$ & $\begin{array}{c}\text { 2. Pozitív } \\
\text { érzelmi } \\
\text { bevonódás } \\
\text { nehézsége }\end{array}$ & $\begin{array}{c}\text { Egészség- } \\
\text { maga- } \\
\text { tartás }\end{array}$ \\
\hline $\begin{array}{l}\text { Párkapcsolati } \\
\text { intimitás } \\
(\text { IBM) }\end{array}$ & Gondoskodás & $0,52^{* *}$ & $0,50^{* *}$ & $-0,48^{* *}$ & $0,35^{* *}$ \\
\cline { 2 - 6 } & Kontroll & $-0,23^{*}$ & $-0,17$ & $0,35^{* *}$ & $-0,13$ \\
\hline $\begin{array}{l}\text { Szülői } \\
\text { bánásmód } \\
(\text { H- PBI) }\end{array}$ & Anyai szeretet & $0,36^{* *}$ & $0,31^{* *}$ & $-0,30^{* *}$ & $0,37^{* *}$ \\
\cline { 2 - 6 } & Anyai túlvédés & $-0,05$ & $-0,08$ & $-0,03$ & $-0,11$ \\
\cline { 2 - 6 } & Anyai korlátozás & $-0,04$ & $-0,07$ & 0,02 & $-0,04$ \\
\cline { 2 - 6 } & Apai szeretet & $0,28^{* *}$ & $0,20^{*}$ & $-0,34^{* *}$ & $0,23^{*}$ \\
\cline { 2 - 6 } & Apai túlvédés & $-0,19^{*}$ & $-0,13$ & $0,26^{* *}$ & $-0,19^{*}$ \\
\cline { 2 - 6 } & Apai korlátozás & 0,01 & 0,01 & 0,03 & 0,04 \\
\hline
\end{tabular}

Megjegyzés: $n=114 .{ }^{*} p<0,05 ;{ }^{* *} p<0,01$. 


\section{Megbeszélés}

Külföldön meglehetősen sok vizsgálat foglalkozik az anya és magzata közötti kapcsolat mérésével, a kötődés minőségét befolyásoló és az egyéni különbségeket magyarázó tényezők leírásával (Yarcheski és mtsai, 2009). A külföldi kérdőívek hazai adaptációja során gyakran validitásbeli nehézségek adódnak - sokszor a kulturális különbségeknek köszönhetően -, így vizsgálatunkban egy saját fejlesztésú mérőeszköz validálására vállalkoztunk. Az általunk összeállított kérdőívvel próbáltuk lefedni azokat a magzati kötődés szempontjából releváns területeket, amelyeket fontosnak gondoltunk az eddigi kutatási eredmények (Salisbury és mtsai, 2003), a terápiás tapasztalatok (Hidas és mtsai, 2008; Leff, 1993), illetve saját gyakorlati munkatapasztalataink alapján.

Ebben a 114 várandós anyával végzett elővizsgálatunkban validáltuk a 28 tételes, 8 alskálát (1. Érzelmek, 2. Gondolatok, fantáziák, jellemző́k tulajdonítása, 3. Magzathoz kapcsolódó tevékenységek, interakciók, 4. Szoptatási szándék, 5. Egészségmagatartás, 6. Anyai kompetencia, 7. Anyaszereppel való azonosulás, 8. Az élmények megosztása) tartalmazó Intrauterin Kötődési Kérdőívet (IUKK). A kérdőív konfirmatív faktoranalízise nem támasztotta alá az elméleti faktorstruktúrát, ezért exploratív faktoranalízissel kívántuk feltárni a méreőszköz faktorszerkezetét. A statisztikai elemzés eredményeként született egy megfelelő illeszkedési mutatókkal rendelkező rövidített változat (IUKK-R), amely 12 tételt és 3 alskálát (1. Megfelelés az elvárt anyai magatartásnak, 2. Pozitív érzelmi bevonódás nehézsége, 3. Egészségmagatartás) tartalmaz, amelyek mindegyike megbízhatónak bizonyult. Mivel ez utóbbi faktor erősen tölt a másik kettőre is, nem tekinthetjük teljesen megalapozottnak, így létjogosultságát mindenképpen érdemes lenne felülvizsgálni a későbbi kutatásokban. Az IUKK-R korrelál az anyamagzat kötődést mérő MFAS-HU-val (Andrek és mtsai, 2016), de az eredmények azt mutatják, hogy a két skála által megragadott dimenziói az anya-magzat kapcsolatnak nem teljesen átfedőek. Ha tartalmilag elemezzük a tételeket, jól látható, hogy a saját kérdőívünk kevésbé a konkrét interakciókra, inkább az érzelmi beállítódásra kérdez rá.

Megvizsgáltuk, hogy vajon a magzathoz való viszony milyen összefüggésben áll néhány szociodemográfiai tényezővel, ezekból néhányat ebben a kutatásban mértünk először (ld. 1. melléklet, Összegző táblázat).

Eredményeink szerint az életkor nem befolyásolja a magzathoz való viszonyulást, aminek az is lehet az oka, hogy nincsenek túl fiatal, kamaszkorú, valamint túlkoros anyák a mintában (a vizsgált anyák életkora 23 és 44 év között mozgott, a KSH (2011) szülőképes korúnak a 15-49 év közötti nőket tekinti). 
A családi állapot a nemzetközi trendhez hasonlóan (Yarcheski és mtsai, 2009) nálunk is meghatározó: a házasságban élő anyáknak összességében erősebb a magzathoz való kötődésük, mint az élettársi kapcsolatban élőknek. A házasságban élőknek magasabb a Megfelelés az elvárt anyai magatartás és alacsonyabb a Pozitív érzelmi bevonódás nehézsége pontszámuk. Úgy túnik, immár sokadszorra nyer igazolást, hogy a házassági kötelék minőségileg más párkapcsolati megélést tesz lehetővé (Kopp \& Skrabski, é.n.; Hadházi, 2002). Ez a szakirodalom szerint azért lehetséges, mert olyan biztonságérzetet ad az anyának, amely segíti ót érzelmileg, gondolatilag elmélyülni, azonosulni az anyaszereppel, jobban bele mer vonódni a folyamatba, kevésbé kétkedik az érzéseiben. Számunkra ez az összefüggés azért is figyelemreméltó, mert a statisztikai adatok alapján Magyarországon a házasságon kívül született gyermekek száma dinamikusan növekedik az ezredforduló óta. 2015-ben 47,8\% volt, sőt a korábbi évhez képest produkált 0,2\%-os születésszám növekedés is teljes mértékben a házasságon kívül született gyermekeknek köszönhető $(0,8 \%)$, míg a házasságban született gyermekek száma (0,3\%-kal) csökkent (KSH, 2016).

A család anyagi bevétele és az iskolázottság az IUKK-R kérdőívvel kapott eredményeink szerint nem befolyásolják az intrauterin kötődést, ugyanakkor minél nagyobb az anya saját anyagi hozzájárulása a család bevételéhez, annál magasabb az Egészségmagatartás skálán elért pontja, valamint az összpontszáma. Az anyagi biztonság megteremtéséhez való hozzájárulás mértékét mindenképpen érdemes lenne longitudinálisan vizsgálni, hiszen a kisbaba születését követően átrendeződésekre lehet számítani. Ha átmenetileg is, de az anya kiesik a kereső tevékenységból bizonyos időre, ami hatással lehet a kompetenciaérzésre, illetve a különböző szerepmegélésekre. Itt jegyezzük meg viszont, hogy az iskolázottságot illetően eredményeinket fenntartással kezeljük, mivel a középfokú végzettségúek alulreprezentáltak a mintánkban.

A korábbi kutatások fényében - ahol a várandósság ideje mérsékelt erősségú előrejelzője volt a magzati kötődésnek $\left(r_{\mathrm{s}}=0,31-0,42\right.$; Yarcheski és mtsai, 2009) - meglepó, hogy kérdőívünk nem bizonyult érzékenynek a várandósság idejére, a fogamzás tervezettségére (tervezte, nem tervezte, nem mostanra tervezte), a fogamzás módjára (természetesen vagy orvosi segítséggel fogant), és a meglévő gyermekek számára. Bár ez utóbbi tényezók az említett metaanalízisben is igen alacsony összefüggést mutattak a prenatális kötődéssel $\left(r_{\mathrm{s}}=0,10-0,20\right)$. Az, hogy a magzathoz való kötődés mintánkon nem korrelál a meglévő gyermekek számával, arra enged következtetni, hogy a méhen belüli kapcsolat egy kitüntetett egyénnel jön létre, és elkülönül a korábbi anyasági élményektól, az anyának a többi gyermekével való kapcsolatától. 
A szakirodalomnak ellentmondó eredményünk, miszerint $a$ várandósság előrehaladtával nem mutat növekedést a magzati kötődés, azt valószínúsíti, hogy a kérdőív olyan emocionális aspektusát érinti a kötődésnek, amely független a várandósság idejétól, azaz nem a várandósság egyes szakaszaiban végbemenó változások implikálta történésekre és magzati interakciókra fókuszál, amint az ismeretes az MFAS-ról (Andrek és mtsai, 2016; Doan és Zimmerman, 2003). Saját eredményeink létjogosultságát támasztja alá Hall és munkatársainak (2015) longitudinális vizsgálati eredménye, amely azt mutatja, hogy a magzat kora születéskor önmagában nem szükségszerúen eredményezi az anyai reprezentáció széttöredezettségét koraszülött és időre született babáknál.

Eredményeink szerint az IUKK-R bizonyos mértékben érzékeny a veszteségekre. A korábban spontán vetélésen átesett anyák alacsonyabb kötődési mutatóval jellemezhetők összességében, valamint, alacsonyabb pontszámot érnek el a Megfelelés az elvárt anyai magatartásnak skálán. Az abortuszra azonban a kérdőív nem jelez. Míg a vetélés spontán megtörténik, előre nem bejósolható, addig az abortusz egy tudatos döntés, még akkor is, ha orvosi indikációja van, ezért a kontroll érzése valamennyire megtartott. Ezen gondolatmenet alapján érthető, hogy a vetélésen átesett anyák óvatosabban vonódnak bele a várandósságba, kevésbé "mernek kötődni a magzatukhoz”. A szakirodalom változatos képet mutat a veszteségek magzati kötődésre gyakorolt hatását illetően (Andrek, Hadházi, \& Kekecs, 2015; Armstrong, 2002), aminek az is lehet az oka, hogy a különböző mérőeszközök más-más aspektusokra helyezik a hangsúlyt. Saját eredményeink azt látszanak megerôsíteni, hogy a veszteségélmények olyan érzelmi lenyomattal bírhatnak, amely hatással van a késóbbi anya-magzat kapcsolatra.

Az anya saját születésének a módja figyelemre méltó tényezőnek bizonyult, és bár kevesen számoltak be a természetestől eltérő születésről (16 fő), ők kevésbé intenzív anya-magzat kötődési mintázatot mutatnak. Alacsonyabb pontszámokat értek el összességében, valamint a Megfelelés az elvárt anyai magatartásnak alskálán és magasabbakat a Pozitív érzelmi bevonódás nehezítettségénél, ami azt mutatja, hogy az IUKK-R érzékeny erre a faktorra. A problematikus, szélsőséges esetben traumatikus születés, a korai kötődést befolyásolva egy esetlegesen nehezebb anya-gyermek kapcsolatot alapozhat meg, amelynek hosszabb távú kihatásai lehetségesek (Müller Nix \& Ansermet, 2009).

A szülő-gyermek kapcsolatot befolyásoló tényezőnek tekintettük a szülők családi állapotát az anya származási családjában (együtt élnek, elváltak, meghaltak), de nem találtunk összefüggést a magzati kötődéssel, ami az egyszülős családok alacsony előfordulási gyakoriságával is magyarázható, de az is lehetséges, hogy általunk nem vizsgált moderátor tényező́kön keresztül érvényesül a hatása, mint például a szülők párkapcsolati elégedettsége. 
A magzat mozgásának érzékelése a szakirodalommal ellentétben (Doan, Cox, \& Zimerman, 2003; Heidrich \& Cranley, 1989) olyan tényezőnek bizonyult, amelyre IUKK-R kérdőív nem érzékeny. Hazai vizsgálati adatok szerint, magának a mozgásnak a megjelenése szignifikáns hatást gyakorol az anyai szelfreferenciára és tagadásra (Stocker \& Hargitai, 2007), azaz a hangsúly az énről a mire, a kapcsolatra tevődik át. Valószínúnek tartjuk, hogy eredményünk annak is tulajdonítható - ami kutatásunk egyik korlátja -, hogy mintánk alig tartalmazott első trimeszterben levő várandóst, így aránylag kevés adatunk van a mozgás megjelenése előtti élményekről. 14 fó mindössze, akik nem, vagy nem biztosan érzik a magzatmozgásokat. Tekintettel arra, hogy alacsony a magzatmozgást nem, vagy nem biztosan érzők száma, nem tudtunk várandóssági hetek szerint differenciálni, azaz megvizsgálni, hogy például, aki 18 hetesen már érzékeli a magzatmozgást, az milyen kötődési értéket mutat, szemben azzal, aki nem. Egy diverzebb mintán végzett vizsgálat valószínúleg kimutatná a szakirodalomban korábban talált trendet. Másrészt, Doan és Zimmermann (2008) érvelése szerint a magzati kötődés ahhoz kapcsolható, hogy az anya mennyire empatikus, illetve mennyire képes kognitív szinten magzata mentális reprezentációjára. Ez utóbbi esetben elképzelhető, hogy a magzatmozgás segítheti ugyan a folyamatot, de semmi esetre sem határozza meg kizárólagosan, így nem szükségszerú, hogy kimutatható legyen a kapcsolata a kötődéssel.

A magzat nemének ismerete sajátosan hat, és a belső biztonsággal hozható összefüggésbe. Ezt a feltételezést támasztja alá, hogy azok, akik biztosan tudják, és akik biztosan nem tudják a magzat nemét, azok magasabb pontszámokat érnek el összességében az IUKK-R kérdőíven, valamint a Megfelelés az elvárt anyai magatartásnak alskálán és alacsonyabbat a Pozitív érzelmi bevonódás nehézsége alskálán, mint azok, akik bizonytalanok a magzat nemét illetően. Úgy túnik, hogy a magzat neméhez kapcsolódó kétségek felerősíthetik az ambivalens érzéseket, nehezítve a kötődést. A magzat nemének ismerete egy olyan prediktor, amit a tudomásunk szerint korábban semmilyen összefüggésben nem vizsgáltak, így eredményeink ebből a szempontból is érdekesek lehetnek.

Mivel a várandós anyának fokozott a támaszigénye (Leff, 1993), fontosnak tartottuk megvizsgálni, hogy a párjától észlelt támogatás, gondoskodás kimutatható szerepet játszik-e a magzatához fúződő kapcsolatában. A párkapcsolati intimitás és anya-magzat kötődés között szignifikáns együttjárást találtunk. Dimenziókra lebontva elmondható, hogy minél eróteljesebb gondoskodást észlel a kismama a párja részéről, annál intenzívebben kötődik a kisbabájához és annál könnyebben adja át magát a várandósságával kapcsolatos pozitív érzéseknek.

Elemzéseink az anyák gyermekkori tapasztalatának fontosságára világítanak rá, hiszen, a szülői bánásmóddal kapcsolatban megállapítható, hogy 
minél szeretőbbnek élte meg az anya a saját szüleit, annál magasabb kötődési pontszámot ér el. Mindez összhangban vannak Siddiqui, Eisemann és Hägglöf (2000), Di Filippo (2010), valamint Baldoni (2010) kutatási eredményeivel, akik szintén az anya korai kapcsolati tapasztalatainak meghatározó szerepét találták. Bár a szülói gondoskodás képességének transzgenerációs átörökítését epigenetikai mechanizmusok biztosítják (Varga, 2011), a modern terápiás elméletek mégis felhívják a figyelmet arra, hogy tudatos odafigyeléssel lehetőségünk van a kedvezőtlen tapasztalatok felülírására (Johnson, 2016).

\section{5. Összegzés, kitekintés}

Magyarországon 2011-ben a gyermekek egyharmadának jólléte egészségügyi és/vagy környezeti okból már a születést megelőzően is veszélyeztetettnek minősült (KSH, 2012), annak ellenére, hogy komoly ellátórendszer foglalkozik a várandósgondozással. Majdnem, hogy természetesnek veszszük, hogy ha a főbb teratogének - fejlődési rendellenességet okozó fizikai, kémiai és biológiai hatások -, jelenlétét minimalizáljuk, akkor a várandósság és a születendő gyermek egészsége optimálisan alakul, ugyanakkor kevés figyelmet fordítunk az érzelmi tényezőkre, az anya és a szülőpár lelki jóllétére.

A jelen elóvizsgálatban alkalmazott 114 fős mintán az általunk kidolgozott Intrauterin Kapcsolati Kérdőív (IUKK) és kiemelten annak rövid változata (IUKK-R), meglehetősen jó faktorstruktúrával, valamint megbízhatósággal rendelkezik és különös tekintettel az összpontszámra, alkalmas az anya-magzat kötődés mérésére. Hazai porondon nem ismert olyan mérőeszköz, amely hasonló reliabilitással fedné le a területet, mivel statisztikailag megbízhatóan vizsgálhatók az aldimenziói is, ami nagy előnye az eddig használatos MFAS-el szemben. Ugyanakkor kérdőívünk validálásvizsgálatát nem tekintjük lezártnak, mivel tisztában vagyunk a vizsgálatunk korlátaival. Mintánk meglehetősen szúk és homogén, és olyan szocioökonómiai jellemzőkkel bír, amelyek a külföldi kutatások eredményei szerint (Alhusan, 2008) korrelálnak a kötődést pozitívan befolyásoló tényezőkkel, úgymint a terhesgondozás hozzáférése és a stabil családi kapcsolatok. A várandósság ideje csak nagyvonalakban körülhatárolt, és nem mértünk olyan tényezóket, amelyek fenyegethetik a kötődést: depressziót, szorongást, vagy a szerhasználatot. A továbbiakban kívánatos lenne a minta reprezentativitására nagyobb hangsúlyt fektetni, az eredmények megbízhatóságának és általánosíthatóságának növelése érdekében.

Összességében a kutatásunkban feltárt prediktorok - amennyiben eredményeink egy nagyobb, reprezentatív mintán replikálásra kerülnek - kiindulási alapul szolgálhatnak a kötődési sérülésre hajlamos anya-magzat- 
párok azonosítására és speciális ellátására. Így kérdőívünk a várandósellátásban, prevencióban alkalmazható mérőeszközként, a célzott támogatás megtervezéséhez nyújthat fogódzót, hozzásegítve az anyát és magzatát, a párt és a családot egy kiegyensúlyozottabb pre- és perinatális idószakhoz.

\section{Irodalomjegyzék}

Alhusan, J.L. (2008). A Literature Update on Maternal-Fetal Attachment. Journal of Obstetric, Gynecologic and Neonatal Nursing, 37, 315-328.

Andrek, A. (1997). A kompetens magzat. In Gy. Hidas (Szerk.), A megtermékenyitéstől a társadalomig (9-20). Budapest: Dinasztia Kiadó

Andrek, A., Hadházi, É., \& Kekecs, Z. (2015). Az anya-magzat kötődés mérésének lehetóségei: első tapasztalataink a Mother fetus Attachment Scale (MFAS) méróeszköz magyar nyelvre fordított változatával és a skála összefüggései demográfiai és pszichoszociális tényezőkkel. In B. Kisdi (Szerk.), Létkérdések a születés körül (367-389). Budapest: L'Harmattan Kiadó

Andrek, A., Hadházi, É., \& Kekecs, Z. (2016). Az anya-magzat kötődést mérő Maternal-Fetal Attachment Scale kérdőív magyar nyelvú adaptálása és felhasználásának lehetőségei az ultrahang-kommunikációs vizsgálatok során. Orvosi Hetilap, 157(20), 789-795.

Andrek, A., Kekecs, Z., Hadházi, É., Boukydis, Z., \& Varga, K. (2016). Re-Evaluation of the Psychometric Properties of the Maternal Fetal Attachment Scale in a Hungarian Sample. Journal of Obstetric, Gynecologic \& Neonatal Nursing, 45(5) e15-e25.

Armstrong, D.S. (2002). Emotional distress and prenatal attachment after perinatal loss. Journal of Nursing Scholarship, 34, 339-345.

Baldoni, F. (2010). Attachment, danger and of the father in the family life span, Erdélyi Pszichológiai Szemle, 4, 375-402.

Barker, D.J.P. (1998). In utero programming of chronic disease. Clinical Science, 95, 115-128.

Beck, C.T. (1999). Available instruments for research on prenatal attachment and adaptation to pregnancy. American Journal of Maternal Child Nursing, 24(1), 25-32.

Bielawska-Batorowicza, E., \& Siddiqui, A. (2008). A study of prenatal attachment with Swedish and Polish expectant mothers. Journal of Reproductive and Infant Psychology, 36(4), 373-384.

Bowen, S.M., \& Miller, B.C. (1980). Paternal Attachment Behaviors Related to Presence at Delivery and Preparenthood Classes: A Pilot Study. Nursing Research, 29, 307-311.

Bowlby, J. (1969). Attachment and Loss: Vol. 1, Attachment. New York: Basic Books

Brandon, A.R., Pitts, S., Denton, W.H., Stringer, C.A., \& Evans, H.M. (2009). A History of the Theory of Prenatal Attachment. Journal of Prenat Perinat Psychol Health, 23(4), 201-222.

Busonera, A., Cataudella, S., Lampis, J., Tommasi, M., \& Zavattini, G.S. (2016). Psychometric properties of a 20-item version of the Maternal-Fetal Attachment Scale in a sample of Italian expectant women, Midwifery 34, 79-87.

Buss, C., Davis, E.P., Muftuler, L.T., Head, K., \& Sandman, C.A. (2010). High pregnancy anxiety during mid-gestation is associated with decreased gray matter density in 6-9-year-old children. Psychoneuroendocrinology, 35, 141-153.

Cannella, B.L. (2005). Maternal-fetal attachment: an integrative review. Journal of Advanced Nursing, 50(1), 60-68.

Cardwell, M.S. (2013). Stress: pregnancy considerations, Obstetrical \& Gynecological Survey, 68(2), 119-129. 
Chamberlain, D. (1998). The Mind of Your Newborn Baby. Berkeley: North Atlantic Books

Charil, A., Laplante, D.P., Vaillancourt, C., \& King, S. (2010). Prenatal stress and brain development, Brain Research Review, 65(1), 56-79.

Condon, J.T. (1993). The assessment of antenatal emotional attachment: development of a questionnaire instrument. British Journal of Medical Psychology, 66, 167-183.

Costello, A.B., \& Osborne, J.W. (2005). Best practices in exploratory factor analysis: four recommendations for getting the most from your analysis. Practical Assessment, Research $\mathcal{E}$ Evaluation, 10(7). Letöltve: 2016.09.26-án: http:/ / pareonline.net/pdf/v10n7.pdf

Cranley, M. (1992). "A ciritical review of prenatal attachment research." Response. Scholarly Inquiry for Nursing Practice, 6, 23-26.

Cranley, M.S. (1981). Development of a tool for the measurement of maternal attachment during pregnancy. Nursing Research, 30, 281-284.

Damato, E.G. (2004). Prenatal attachment and other correlates of postnatal maternal attachment to twins. Advances in Neonatal Care, 4(5), 274-291.

Di Filippo, L. (2010). The effect of psycho-social risk in the development of mother-child relationship during the first year of childhood, Erdélyi Pszichológia Szemle, 4, 203-222.

DiPietro, J.A., Hodgson, D.M., Costigan, K.A., \& Johnson, T.R. (1996). Fetal antecedents of infant temperament. Child Development, 67(5), 2568-2583.

Doan, H. McK, Cox, N.I., \& Zimerman, A. (2003). The Maternal Fetal Attachment Scale: some methodological ponderings. Journal of Prenatal and Perinatal Psychology and Health, 18(2), 167-188.

Doan, H. McK, \& Zimerman, A. (2003). Conceptualizing Prenatal Attachment: Toward a Multidimensional View. Journal of Prenatal and Perinatal Psychology and Health, 18, 131-148.

Doan, H.McK., \& Zimerman, A. (2008). Prenatal attachment: A developmental model. International Journal of Prenatal and Perinatal Psychology and Medicine, 20(1-2), 20-28.

Dunkel Schetter, C. (2011). Psychological science on pregnancy: stress processes, biopsychosocial models and emerging research issues. Annual Review of Psychology, 62, 531-558.

Dunkel Schetter, C., \& Tanner, L. (2012). Anxiety, depression and stress in pregnancy: implications for mothers, children, research, and practice. Behavioural Medicine, 25(2), 141-148.

Erickson, M. (1996). Predictors of maternal-fetal attachment: An integrative review. The Online Journal of Knowledge Synthesis for Nursing, 3(1), 56-72.

Esch, T., \& Stefano, G.B. (2005). The Neurobiology of Love. Neuro Endocrinology Letters, 26(3), 175-192.

Field, A. (2013). Discovering statistics using IBM SPSS statistics. London: Sage

Fónagy, P., Steele H., \& Steele, M. (1991). Maternal representations of attachment during pregnancy predict the organization of infant mother attachment at one year of age. Child Development, 62, 891-905.

Gérecz, Á., \& Hadházi, É. (2014). Intimitás, a kötődés, szülői bánásmód és depresszió függvényében. In M. Vassányi, J. Fülöp, \& Zs. Mirnics (Szerk.), Kapcsolatban Istennel és emberrel. Pszichológiai és bölcsészeti tanulmányok (32-54). Budapest: L'Harmattan Kiadó

Gergely, Gy., \& Watson, J.S. (1998). A szülői érzelmi tükrözés szociális biofeedback modellje, Thalassa, 9(1), 56-105.

Gopnik, A. (2009). A babák filozófiája. Budapest: Nexus

Hadházi, É. (2002). A gyermekvárás és a koragyermekkor időszakában kialakuló szülői attitüdök vizsgálata. PhD Disszertáció. Debrecen: Kossuth Lajos Tudományegyetem

Hadházi, É. (2012). Az érintés párkapcsolati összefüggései, női szemmel. Előadás. Magyar Pszichiátriai Társaság XVII. Vándorgyúlése: „Test, Lélek, Család, Közösség. A fejlődő pszichiátria határai". Debrecen: 2012. január 25-28. 
Hadházi, É., Gérecz, Á., \& Végh, F. (2011). Az intimitás mérése - előzetes eredmények magyar mintán - „Hagyomány és megújulás”. Poszter. A Magyar Pszichológiai Társaság Jubileumi XX. Országos Tudományos Nagygyúlése. Budapest: 2011. május 25-27.

Hall, R.A.S., Hoffenkamp, H.N., Tooten, A., Braeken, J., Vingerhoets, A.J.J.M., \& Van Bakel, H.J.A. (2015). Longitudinal Associations Between Maternal Disrupted Representations, Maternal Interactive Behavior and Infant Attachment: A Comparison Between Full-Term and Preterm Dyads. Child Psychiatry Human Development, 46, 320-331.

Hedegaard, M., Henriksen, T.B., Sabore, S., \& Secher, N.J. (1993). Psychological distress in pregnancy and preterm delivery. British Medical Journal, 307(6898), 234-239.

Heidrich S. M., \& Cranley, M. S.: Effect of fetal movement, ultrasound scans, and amniocentesis on maternal-fetal attachment during pregnancy. Nursing Research, 38(2), 81-84.

Hidas, Gy. (1997). Bevezetés. In Gy. Hidas (Szerk.), A megtermékenyitéstől a társadalomig (5-8). Budapest: Dinasztia Kiadó

Hidas Gy., Raffai J., \& Vollner J. (2008). Lelki köldökzsinór. Budapest: Helikon Kiadó

Hooper, D., Coughlan, J., \& Mullen, M. (2008). Structural equation modelling: Guidelines for determining model fit. Electronic Journal of Business Research Methods, 6(1), 53-60.

Huizink, A.C. (2001). Prenatal stress and its effect on infant development. Dissertation. Utrecht: Utrecht University. Letöltve: 2016.10.30-án: https:/ / dspace.library.uu.nl/bitstream/ handle/1874/371/inhoud.htm;jsessionid=EEDDB0BED177A9BCBF199DD7BE145AD 6 ? sequence $=8$

Johnson, S.M. (2016). Az érzelmekre fókuszáló párterápia gyakorlata. Budapest: Oriold és Társai Kiadó

King, S., \& Laplante, D.P. (2005). The effects of prenatal maternal stress on children's cognitive development: Project Ice Storm, Stress, 8, 35-45.

Kinsella, M.T., \& Monk, C. (2009). Impact of maternal stress, depression \& anxiety on fetal neurobehavioral development. Clinical Obstetrics \& Gynecology, 52(3), 425-440.

Kopp M., \& Skrabski Á. (é.n.). Nók és férfiak egészségi állapota Magyarországon. Letöltve: 2016.10.11-én: www.tarsadalokutatats.hu/kkk.php?TPUBL-A-882/publikaciok/ tpubl-a-882.pdf

KSH (2011). Gyermekvállalás és gyermeknevelés. letöltve: 2015.03.05. www.demografia. hu

KSH (2012). Születés körüli halálozások Magyarországon, 2011, Statisztikai tükör, 6(88). Letöltve: 2016.10.30-án: https://www.ksh.hu/docs/hun/xftp/stattukor/ szuleteshalalozas11.pdf

KSH (2016). Magyarország 2015. Letöltve: 2016.09.30-án: https:/ /www.ksh.hu/docs/hun/ xftp/idoszaki/mo/mo2015.pdf

Leff, J.R. (1993). Pregnancy. The inside story. London: Sheldon Press

Lerum, C.W., \& LoBiondo-Wood, G. (1989). The relationship of maternal age, quickening, and physical symptoms of pregnancy to the development of maternal-fetal attachment. Birth, 16(1), 13-17.

Magyar Közlöny (2014). A várandósgondozásról. 26/2014. (IV. 8.) EMMI rendelet, Magyar Közlöny, 52, 4937- 4943.

Makino, I., Matsuda, Y., Yoneyama, M., Hirasawa, K., Takagi, K., Ohta, H., et al. (2009). Effect of maternal stress on fetal heart rate assessed by vibroacoustic stimulation. Journal of International Medical Research, 37(6),1780-1788. Letöltve: 2016.01.10-én: http=// www.ncbi.nlm.nih.gov/pubmed/20146876

Markin, R.D (2013). Mentalization-based psychotherapy interventions with mothers-to-be. Psychotherapy, 50(3), 360-365. 
Martin, R.P., \& Dombrowski, S.C. (2008). Prenatal exposures: Psychological and educational consequences for children. New York: Springer

Mazzeschi, C., Pazzagli, C., Radi, G., Raspa, V., \& Buratta, L. (2015). Antecedents of maternal parenting stress: the role of attachment style, prenatal attachment, and dyadic adjustment in first-time mothers. Frontiers in Psychology, 6:1443. Letöltve: 2016.10.11-én: https:/ / www.ncbi.nlm.nih.gov/pmc/articles/PMC4585159/

Monk, C., Fifer, P.W., Myers, M.M., Sloan, R.P., Trien, L., \& Hurtado, A. (2000). Maternal stress responses and anxiety during pregnancy: Effects on fetal heart rate, Developmental Psychobiology, 36(1), 67-77.

Mulder, E.J, Robles de Medina P.G., Huizink A.C., Van den Bergh, B.R., Buitelaar, J.K., \& Visser, G.H. (2002). Prenatal maternal stress: effects on pregnancy and the (unborn) child. Early Human Development, 70(1-2), 3-14.

Müller, M.E., \& Mercer, R.T. (1993). Development of the Prenatal Attachment Inventory. Western Journal of Nursing Research, 15(2), 199-215.

Müller, M.E., \& Ferketich, S. (1993). Factor Analysis of the Maternal Fetal Attachment Scale. Nursing Research, 42, 144-147.

Müller, M.E. (1993). Development of the Prenatal Attachment Inventory, Western Journal of Nursing Research, 15, 199-215.

Müller, M.E. (1996). Prenatal and postnatal attachment: a modest correlation. Journal of Obstetric, Gynecologic and Neonatal Nursing, 25, 161-166.

Müller Nix, C. \& Ansermet, F. (2009). Prematurity, Risk factors, and protective Factors. In Ch. Zeneah (Ed.), Handbook of Infant Mental Health (180-196). New York: The Guilford Press

Parker, G., Tulping, H., \& Brown, L.B. (1979). A Parental Bonding Instrument. British Journal of Medical Psychology, 52, 1-10.

Pisoni, C., Garofolit, F., Tzialla, C., Orcesi, S., Spinillo, A., Politi, P., et al. (2014). Risk and protective factors in maternal-fetal attachment development, Early Human Development, 90(S2), 45-46.

Rubin, R. (1984). Maternal identity and the maternal experience. New York: Springer Publishing Company.

Salisbury, A., Law, K., LaGasse, L., \& Lester, B. (2003). Maternal-Fetal Attachment. The Journal of the American Medical Association, 289(13), 1701-1702.

Stocker, A. K., \& Hargitai, K. (2007). Az anya-magzat kötődés narratív pszichológiai vizsgálata. Pszichológia, 27(3), 239-259.

Siddiqui, A., \& Hägglöf, B. (2000). Does maternal prenatal attachment predict postnatal mother infant interaction?, Early Human Development, 59(1), 13-25.

Siddiqui, A., Eisemann, M., \& Hägglöf, B. (2000). Own memories of upbringing as a determinant of prenatal attachment in expectant women. Journal of Reproductive and Infant Psychology, 18(1), 67-74.

Sz. Makó, H., \& Deák, A. (2014). Reliability and Validity of the Hungarian Version of the Maternal Antenatal Attachment Scale. International Journal of Gynecological and Obstetrical Research, 1, 33-44.

Tegethoff, M., Greene, N., Olsen, J., Schaffner, E., \& Meinlschmidt, G. (2011). Stress During Pregnancy and Offspring Pediatric Disease: A National Cohort Study. Environmental Health Perspectives, 119(11), 1647-1652.

Tóth, I., \& Gervai, J. (1999). Szülői Bánásmód Kérdőív (H-PBI). A Parental Bonding Instrument (PBI) magyar változata. Magyar Pszichológiai Szemle, 54(4), 551-566.

Yarcheski, A., Mahon, N.E., Yarcheski, T. J., Hanks, M.M., \& Canella, B. L. (2009). A metaanalytic study of predictors of maternal-fetal attachment. International Journal of Nursing Studies, 46, 708-715. 
Van den Bergh, B. (1990). The influence of maternal emotions during pregnancy on fetal and neonatal behavior. Pre and Perinatal Psychology, 5, 119-130.

Varga, K. (2011). A transzgenerációs hatások az epigenetikai kutatások tükrében. Magyar Pszichológiai Szemle, 66(3), 507-532.

Wilhelm, K., \& Parker, G. (1988). The development of a measure of intimate bonds. Psychological Medicine, 18(1), 225-234.

\section{Köszönetnyilvánítás}

Ezúton szeretnénk köszönetet mondani Héjja Anna és Illés Szilvia pszichológusoknak az IUKK kérdőív tételeinek meghatározásában nyújtott aktív közremúködésükért, valamint a vizsgálatban résztvevő minden kismamának a kérdőívcsomag lelkiismeretes kitöltéséért, a védőnőknek, egészségügyi személyzetnek a vizsgálati személyek tájékoztatásáért és a kérdőívek átadásáért.

\section{Nyilatkozat érdekütközésról}

A szerzők ezúton kijelentik, hogy esetükben nem állnak fenn érdekütközések.

\section{Melléklet: Összegző táblázat}

\begin{tabular}{|l|l|}
\hline $\begin{array}{c}\text { Szociodemográfiai, várandóssághoz } \\
\text { kapcsolódó és pszichológiai tényezók, } \\
\left.\text { amelyek számottevó ( } r_{s} \geq 0,3\right), \\
\text { szignifikáns lineáris kapcsolatban vannak } \\
\text { a magzati kötődéssel }\end{array}$ & IUKK-R \\
\hline Családi állapot & $\begin{array}{l}\text { Összpontszám } \\
\text { Megfelelés az elvárt anyai magatartásnak } \\
\text { Pozitív érzelmi bevonódás nehézsége }\end{array}$ \\
\hline $\begin{array}{l}\text { Az anya anyagi hozzájárulása a családi } \\
\text { egzisztenciához }\end{array}$ & $\begin{array}{l}\text { Összpontszám } \\
\text { Egészségmagatartás }\end{array}$ \\
\hline Vetélés* & $\begin{array}{l}\text { Összpontszám } \\
\text { Megfelelés az elvárt anyai magatartásnak }\end{array}$ \\
\hline $\begin{array}{l}\text { Az anya születésének körülményei } \\
\text { (természetes vs. beavatkozással) * }\end{array}$ & $\begin{array}{l}\text { Összpontszám } \\
\text { Megfelelés az elvárt anyai magatartásnak } \\
\text { Pozitív érzelmi bevonódás nehézsége }\end{array}$ \\
\hline A magzat nemének ismerete* & $\begin{array}{l}\text { Összpontszám } \\
\text { Megfelelés az elvárt anyai magatartásnak } \\
\text { Pozitív érzelmi bevonódás nehézsége }\end{array}$ \\
\hline
\end{tabular}




\begin{tabular}{|c|c|}
\hline $\begin{array}{l}\text { Párkapcsolati intimitás: észlelt } \\
\text { gondoskodás* }\end{array}$ & $\begin{array}{l}\text { Összpontszám } \\
\text { Megfelelés az elvárt anyai magatartásnak } \\
\text { Pozitív érzelmi bevonódás nehézsége } \\
\text { Egészségmagatartás }\end{array}$ \\
\hline Párkapcsolati intimitás: észlelt kontroll* & Pozitív érzelmi bevonódás nehézsége \\
\hline $\begin{array}{l}\text { Az anyai szülói bánásmód: anyai } \\
\text { szeretet }^{*}\end{array}$ & $\begin{array}{l}\text { Összpontszám } \\
\text { Megfelelés az elvárt anyai magatartásnak } \\
\text { Egészségmagatartás }\end{array}$ \\
\hline Az anyai szülői bánásmód: apai szeretet ${ }^{*}$ & Pozitív érzelmi bevonódás nehézsége \\
\hline $\begin{array}{l}\text { Tényezók, amelyek nem mutattak } \\
\text { szignifikáns kapcsolatot a magzati } \\
\text { kötődéssel: } \\
\text { Életkor } \\
\text { Iskolázottság } \\
\text { Várandósság ideje } \\
\text { Abortusz* } \\
\text { Bármilyen veszteség* } \\
\text { A várandósság tervezettsége, a fogantatás } \\
\text { módja } \\
\text { Testvérek, korábbi gyermekek } \\
\text { A magzat mozgásának érzékelése } \\
\text { Az anya származási családjában a szülők } \\
\text { családi állapota* } \\
\text { Az anyai szülői bánásmód: apai túlvédés* }\end{array}$ & \\
\hline
\end{tabular}

Megjegyzés: * a korábbi kutatásokban még nem vizsgált prediktorok. 


\section{Függelék: Intrauterin Kapcsolati Kérdóív (IUKK)}

Az alábbiakban a gyermekvárással kapcsolatos állításokat talál. A kérdésekre nincsenek jó, vagy rossz válaszok, hiszen minden élménynek megvan a maga létjogosultsága. Kérjük minden egyes állítás esetében döntse el, hogy milyen mértékben igaz Önre és az Ön tapasztalatainak leginkább megfelelő választ jelölje be.

\begin{tabular}{|c|c|c|c|c|}
\hline & $\begin{array}{l}\text { Tökéle- } \\
\text { tesen } \\
\text { igaz }\end{array}$ & $\begin{array}{l}\text { Több- } \\
\text { nyire } \\
\text { igaz }\end{array}$ & $\begin{array}{l}\text { Kismér- } \\
\text { tékben } \\
\text { igaz }\end{array}$ & $\begin{array}{l}\text { Egyálta- } \\
\text { lán nem } \\
\text { igaz }\end{array}$ \\
\hline $\begin{array}{l}\text { 1. Könnyen döntöttem a gyermekvállalás } \\
\text { mellett. }\end{array}$ & 3 & 2 & 1 & 0 \\
\hline $\begin{array}{l}\text { 2. Könnyú elképzelnem, hogyan nézhet ki } \\
\text { a kisbabám. }\end{array}$ & 3 & 2 & 1 & 0 \\
\hline $\begin{array}{l}\text { 3. Jobban odafigyelek magamra, amióta } \\
\text { babát várok. }\end{array}$ & 3 & 2 & 1 & 0 \\
\hline 4. Jó érzés a kisbabámra gondolni. & 3 & 2 & 1 & 0 \\
\hline $\begin{array}{l}\text { 5. Már most erőfeszítéseket teszek azért, } \\
\text { hogy jó anya legyek. }\end{array}$ & 3 & 2 & 1 & 0 \\
\hline $\begin{array}{l}\text { 6. Szívesen megosztom a várandóssággal } \\
\text { kapcsolatos élményeimet. }\end{array}$ & 3 & 2 & 1 & 0 \\
\hline 7. Az anyaság megváltoztatott. & 3 & 2 & 1 & 0 \\
\hline 8. Élvezem ezt az állapotot. & 3 & 2 & 1 & 0 \\
\hline $\begin{array}{l}\text { 9. Szeretném minél tovább szoptatni } \\
\text { a kisbabámat. }\end{array}$ & 3 & 2 & 1 & 0 \\
\hline $\begin{array}{l}\text { 10. Úgy érzem, könnyen oda tudok } \\
\text { szentelődni az anyaszerepnek. }\end{array}$ & 3 & 2 & 1 & 0 \\
\hline $\begin{array}{l}\text { 11. Előfordul, hogy nyomaszt az anyai } \\
\text { felelősség. }\end{array}$ & 3 & 2 & 1 & 0 \\
\hline $\begin{array}{l}\text { 12. Félek belegondolni, hogy akár } \\
\text { visszafordíthatatlan változások is } \\
\text { mehetnek végbe a testemen. }\end{array}$ & 3 & 2 & 1 & 0 \\
\hline $\begin{array}{l}\text { 13. Fontosnak tartom a minél gyakoribb } \\
\text { visszajelzéseket a kisbabám fejlődéséről. }\end{array}$ & 3 & 2 & 1 & 0 \\
\hline $\begin{array}{l}\text { 14. Időnként nehéznek érzem, } \\
\text { hogy a baba most csak rám van utalva. }\end{array}$ & 3 & 2 & 1 & 0 \\
\hline
\end{tabular}




\begin{tabular}{|c|c|c|c|c|}
\hline & $\begin{array}{l}\text { Tökéle- } \\
\text { tesen } \\
\text { igaz }\end{array}$ & $\begin{array}{l}\text { Több- } \\
\text { nyire } \\
\text { igaz }\end{array}$ & $\begin{array}{l}\text { Kismér- } \\
\text { tékben } \\
\text { igaz }\end{array}$ & $\begin{array}{l}\text { Egyálta- } \\
\text { lán nem } \\
\quad \text { igaz }\end{array}$ \\
\hline $\begin{array}{l}\text { 15. A kisbabák táplálásának a szoptatáson } \\
\text { kívül más módjait is megfelelőnek tartom. }\end{array}$ & 3 & 2 & 1 & 0 \\
\hline $\begin{array}{l}\text { 16. Szeretnék minél tájékozottabb lenni az } \\
\text { anyasággal kapcsolatban. }\end{array}$ & 3 & 2 & 1 & 0 \\
\hline $\begin{array}{l}\text { 17. Gyakran az jár az eszemben, hogy } \\
\text { vajon mit csinálhat a kisbabám. }\end{array}$ & 3 & 2 & 1 & 0 \\
\hline $\begin{array}{l}\text { 18. Változtattam az életritmusomon, } \\
\text { mióta várandós vagyok. }\end{array}$ & 3 & 2 & 1 & 0 \\
\hline $\begin{array}{l}\text { 19. Úgy hiszem, hogy a szoptatásnak } \\
\text { a tápláláson kívül más funkciója is lehet. }\end{array}$ & 3 & 2 & 1 & 0 \\
\hline $\begin{array}{l}\text { 20. Több figyelmet fordítok az } \\
\text { egészségemre, mióta várandós vagyok. }\end{array}$ & 3 & 2 & 1 & 0 \\
\hline $\begin{array}{l}\text { 21. Nem beszélek szívesen a babámmal } \\
\text { kapcsolatos érzéseimról. }\end{array}$ & 3 & 2 & 1 & 0 \\
\hline $\begin{array}{l}\text { 22. Igyekszem minél tájékozottabb lenni } \\
\text { a kisbabám állapotával kapcsolatban. }\end{array}$ & 3 & 2 & 1 & 0 \\
\hline $\begin{array}{l}\text { 23. Inkább magamban tartom az } \\
\text { állapotommal kapcsolatos, esetleges } \\
\text { nehézségeimet. }\end{array}$ & 3 & 2 & 1 & 0 \\
\hline $\begin{array}{l}\text { 24. Örömmel töltött el a várandósságom } \\
\text { híre. }\end{array}$ & 3 & 2 & 1 & 0 \\
\hline $\begin{array}{l}\text { 25. A szokványos tevékenységek közben } \\
\text { is eszembe jut, hogy milyen hatással } \\
\text { lehetnek azok a kisbabámra. }\end{array}$ & 3 & 2 & 1 & 0 \\
\hline $\begin{array}{l}\text { 26. Szívesen mondok le olyan } \\
\text { tevékenységekról, amikról úgy érzem, } \\
\text { hogy zavarhatják a kisbabámat. }\end{array}$ & 3 & 2 & 1 & 0 \\
\hline $\begin{array}{l}\text { 27. Úgy gondolom, hogy a kismamák túl } \\
\text { sokat beszélnek a várandósságról. }\end{array}$ & 3 & 2 & 1 & 0 \\
\hline $\begin{array}{l}\text { 28. Úgy érzem, hogy a lehető legjobb } \\
\text { helyen van nálam ez a baba. }\end{array}$ & 3 & 2 & 1 & 0 \\
\hline
\end{tabular}

Fordított tételek: 11., 12., 14., 15., 21., 23. és 27. tétel.

A skálaképzés a tételek összeadásával történik.

A rövidített változat (IUKK-R) tételeit aláhúzással emeltük ki. 


\title{
Preliminary results of the reliability and validity of the Intrauterine Relationship Questionnaire, a scale developed on a Hungarian sample - pilot study
}

\author{
Investigation of the mother-fetus attachment and its correlation \\ with partnership and parental bonding \\ HADHÁZI, ÉVA - ANDREK, ANDREA - KEKECS, ZOLTÁN
}

Background: The effects of "maternal environment" on fetal development have been studied since the eighties, but the results regarding the features which influence mother-fetus relationship are inconsistent. Aim: To develop a mother-fetus relationship assessment scale on a Hungarian sample, and to reveal the factors that determine mother-fetus bonding. Method: 114 pregnant women, between 15 and 38 weeks of gestational age, filled out the Intrauterine Relationship Questionnaire, the Hungarian version of Maternal Fetal Attachment Scale, Intimate Bond Measurement and Parental Bonding Instrument. Results: our 28 items Intrauterine Relationship Questionnaire's (IURQ) factor structure indicators proved to remain below the expectations $\left(\mathrm{RMSEA}=.08, \chi^{2} / \mathrm{df}=1.645, \mathrm{NFI}=.85, \mathrm{CFI}=.87\right.$ ). The eight subscales' Cronbach's alphas are between .56 and .93 . With exploratory factor analysis we managed to develop a shortened version model (IURQ-S), with better psychometric characteristics, which contains 12 items and 3 subscales (RMSEA $=.08, \mathrm{X}^{2}$ / $\mathrm{df}=1.660, \mathrm{NFI}=.95, \mathrm{CFI}=.96)$. The internal consistency of IURQ-S is high, Cronbach's alphas range from .81 to .93. For further analyses we used the IURQ-S model. Our questionnaire correlate with MFAS-HU but their dimensions are not entirely overlapping. In accordance with international experiences we found that a mother reaches significantly higher scores on the mother-fetus relationship scale, if she can be characterized with any of the following: married, has high contribution to family income, no previous experience of miscarriage, born in natural way, without any intervention, definitely knows or definitely does not know the fetus' sex. The time of the pregnancy had no substantial effect, neither had the educational background of the mother or whether the pregnancy was planned. The method of conception, the number of children born previously and the fetal movement did not prove to be decisive either. Fetal attachment correlated with partnership intimacy: higher mother-fetus attachment scores were found with higher perceived care and lower perceived control. The mother's own parental bonding, her perceived maternal and paternal love was found to be in positive correlation with her attachment to her fetus. Conclusions: The questionnaire reliability is promising, but further validity examinations are needed in a larger, more heterogeneous sample. The results have drawn our attention to the importance of parental bonding and perceived partner care during pregnancy, and can help prevention of early attachment disfunction.

Keywords: intrauterin attachment, mother-fetus relationship, partnership intimacy, parental bonding 